DOI: http://dx.doi.org/10.24818/jamis.2020.03004

\title{
Reporting on Sustainable Development Goals. A score-based approach with company-level evidence from Central-Eastern Europe economies
}

\author{
Elena-Mirela Nichita ${ }^{\mathrm{a}, 1}$, Elena Nechita ${ }^{\mathrm{a}}$, Cristina-Lidia Manea ${ }^{\mathrm{a}}$, \\ Diana Manea $^{\mathrm{a}}$ and Alina-Mihaela Irimescu ${ }^{\mathrm{a}}$
}

a Bucharest University of Economic Studies, Romania

\begin{abstract}
Research Question: Which chemical companies from CEE countries are pioneers in both disclosing SDGs achievements and progressing in fulfilling self-imposed targets? Motivation: Revealing SDGs is unfruitful if it is not supported by relevant indicators to highlight progress against targets (EY, 2017; Schramade, 2017). The strategic importance of the chemical industry, one of the most diversified from all industries, creates sound circumstances for this sector to make known all efforts and contributions towards sustainability engagements (Aga, 2012; Zimara \& Eidam, 2015).

Idea: Beside financial reporting, currently businesses are encouraged to publish nonfinancial information to express their awareness about nature and human capital. The chemical industry should consider the SDGs a catalyst for significant business opportunities and a contributor for a better life, across sector and through cooperation with other sectors. Data: In this paper we used a set of panel data extracted from non-financial reports and websites of the 10 largest companies in the chemical industry operating in countries from Central-Eastern Europe: Czech Republic, Hungary, Poland, Romania, and Slovakia. Our analysis covers the period 2015-2019 and addresses the disclosure and progress on reporting SGDs.

Tools: To assess the degree of disclosure regarding SDGs and the advancement alongside companies' efforts to comply with UN goals, we carried out a textual and content analysis, then we developed a score, with qualitative and quantitative features, to deliberate the disclosure of SDGs information incorporated in reports.

Findings: Our discoveries indicate that $63 \%$ of the analysed reports did not clearly mention the SDGs that were targeted by companies' investments. This result noticeably points out that SDGs reporting is presented relatively dissimilar, with reference to structure and extent, among the analysed companies, even though they are part of the same industry.

1 Corresponding author: Elena-Mirela Nichita, Department of Accounting and Audit, Bucharest University of Economic Studies, Romania, Piata Romana, no. 6; email address: mirela.nichita@cig.ase.ro
\end{abstract}


Contribution: We consider this paper may be valuable to scholars in their journey considering, assessing and developing original approaches in regard to researches about non-financial reporting, in general, and SDGs, in particular, nevertheless, to businesses to advance in their accomplishments and reporting on the topic of SDGs.

Keywords: Sustainable Development Goals (SDGs), chemical industry, CentralEastern Europe (CEE) economies, score-based approach, content analysis, non-financial reporting, disclosure

JEL codes: M14, M21, Q01, Q56

\section{Introduction}

Since the introduction of UN World Commission on Environment and Development Report (WCED), extensive range of initiatives have been conducted at numerous levels in order to tackle the growing number of environmental and social concerns. One forward step towards the encouragement of sustainable development on a global scale was established in 2015 with the creation of the Paris Agreement. This agreement provided a new understanding of the UN Sustainable Development Goals (SDGs). The Paris Agreement has put in place an ambitious itinerary to achieve zero-emission practices in countries and businesses around the world in little more than a generation, based on the World Business Council for Sustainable Development (WBCSD, 2018). In 2015, the UN General Assembly officially approved the 2030 Agenda for Sustainable Development together with a set of 17 Sustainable Development Goals (SDGs) and 169 associated objectives (UN, 2015).

Monitoring and quantifying the impact of Agenda 2030 requires measuring SDGs and sustainable development, which is filled with challenges (Swain and YangWallentin, 2019). Nicolai et al. (2015) accentuates the necessity of considerable efforts to be successful with SDGs until 2030. A different point of view is highlighted by Easterly (2015), who argues that the SDGs are underrated goals, exhaustive, where everything is top priority, implying that nothing is a priority.

The Sustainable Development Goals display an inspiring vision of what the world could look like in future. The adoption of these global goals comes at a time when we are daily reminded that the challenges we face - migration, conflict, climaterelated disasters, pandemics - cannot be solved by individual countries. Solutions to these imperative issues can only be found in a properly global attempt, with all countries dedicated to accomplishing this bold objective (Nicolai et al., 2015).

However, the model of sustainable development is unfamiliar and new for companies operating in Central-Eastern European (CEE) countries and in some 
way, this is considered a targeted development challenge (Raszkowski \& Bartniczak, 2019). For countries part of CEE, the post-communist era (1990 upward) has come with many structural ups and downs accompanied with uncertainties; these countries face socio-economic difficulties, as high unemployment rates, high rate of emigration of the population, low purchasing power of households, political hesitations, and the quality of legislation, to name few of them. Essentially, sustainable development is a process of change through which resource exploitation, investment direction, technological development orientation, and institutional changes are harmonically leading to the improvement of the quality of human life, bringing together people, nature and businesses (Nechita, 2019).

Recent publications concerning SDGs reporting pinpoint the lack of clear reporting requirements in the sphere of sustainable development, which complicates the processes of assessing the contribution of economic entities to the achievement of the SDGs (EU, 2019; Kornieieva, 2020).

The focus of the current academic work is on non-financial information disclosed by first 10 largest companies from the chemical industry operating in Czech Republic (CZ), Hungary (HU), Poland (PL), Romania (RO) and Slovakia (SK) in respect to SDGs; the analysis covers period 2015 to 2019. The textual and content analysis of companies' reports reveals the interest of chemical companies in diverse goals and resourceful presentation of information in numerous types of reports. Our research is relevant for the academic community contributing to the contemporary debate concerning SDGs disclosure and progress, as well for businesses to advance in their engagements and reporting on the topic of SDGs.

To achieve our objective, the paper is organized as follows: the literature review section highlights the development of SDGs, progresses concerning the integration of SDGs in reporting by corporations operating in CEE countries and transforming role of accounting in reporting SDG; the methodology details the approaches and procedures used in selecting the data, results and discussion section provides our perceptions in respect to SDGs disclosed by chosen companies. The paper will close with a discussion section, conclusion and future research agenda in this subject.

\section{Literature review}

In today's complex business landscape, companies are expected to deliver more than profits and shareholder value: they are increasingly focusing on their nonfinancial performance (Bonini \& Swartz, 2014), consequently, the idea of corporate sustainability has become part of mainstream business discourse. To understand the role of sustainability initiatives in business, we looked at academic 
studies, investor strategies, and professional organizations surveys on non-financial reporting and SDGs.

\subsection{Introduction to Sustainable Development Goals - synopsis}

The business environment is experiencing profound changes, encouraged by powerful demographic shifts, global economic and societal forces, and emerging technologies. At the same time, society is increasingly demanding companies to become more accountable for their actions, display a greater sense of social responsibility, and embrace more sustainable practices. These trends send a strong signal that what business needs today is much more diverse and different from what it needed yesterday or will need tomorrow. Therefore, a stakeholder approach (Freeman, 1984) is suitable to cope with all demands and expectations.

Since the introduction of UN World Commission on Environment and Development Report, extensive range of initiatives have been conducted at numerous levels in order to tackle the growing number of environmental and social concerns. One forward step towards the encouragement of sustainable development on a global scale was established in 2015 with the creation of the Paris Agreement. This agreement provided a new understanding of the UN Sustainable Development Goals (SDGs). The Paris Agreement has put in place an ambitious itinerary to achieve zero-emission practices in countries and businesses around the world in little more than a generation, based on the World Business Council for Sustainable Development (WBCSD). In 2015, the UN General Assembly officially approved the 2030 Agenda for Sustainable Development together with a set of 17 Sustainable Development Goals (SDGs) and 169 associated objectives (UN, 2015). This framework contains better coverage of, and balance between, the economic, social and environmental dimensions of sustainable development and provides an opportunity to activate systemic change towards a sustainable future (Costanza et al., 2016). A major challenge to advancing sustainable development in the past consisted in the lack of methodologies that facilitate a comprehensive, multidimensional, and dynamic perspective, as well as tools to evaluate the tradeoffs and interactions among the economic, social and environmental dimensions of development (Scrieciu, 2007).

Sustainable development certainly "means different things to different people" (Aras \& Crowther, 2008; Cordova \& Celone, 2019). As such, sustainable development has proved a fascinating, but an elusive and abstract paradox (Adelson et al., 2008). Ramirez (2012) has argued that this enigma reflects the tension between the potentially positive effects of economic growth on poverty and employment with the damaging impact of such growth on the environment's natural resources and on traditional societies and ways of life in many parts of the less developed world. 
Reporting on Sustainable Development Goals. A score-based approach with companylevel evidence from Central-Eastern Europe economies

While the professional community is clearly accentuating the need to adopt evidence-based and science-based approaches to SDGs implementation, policymakers face the challenge of simultaneously implementing the SDGs in a coherent and integrated manner. With an increasing number of developed and developing countries turning their attention to implementation of the SDGs, there is a considerable risk that countries will pursue the same "siloed" or "linear" approaches to sustainable development that have met with limited success in the past. Regular systematic reviews of national progress and approaches to implementing the SDGs are therefore desirable to ensure that emerging science and knowledge are effectively informing national practice (Allen et al., 2018; European Parliament, 2019). Inconsistencies in measurement indicators lead Miola and Schiltz (2019) to accentuate that countries can receive substantially different relative evaluations depending on methods used to measure SDGs performance for EU28 zone.

\subsection{Reporting SDGs in Central Eastern Europe - emphasis on integrating SDGs in non-financial reporting}

Since 2007, Gazdar had anticipated that non-financials are meant to go beyond financial disclosure and provide stakeholders with a deeper, more balanced view of the company. In this midst of a significant restructuring, the non-financial rating landscape is adapting to new challenges: Sustainable Development Goals (SDGs). After an emphasis on assessing investment portfolio in businesses with prominence attention on environment, climate, social aspects, the business communities are progressing towards a new emerging phenomenon: measuring corporate performance based on the SDGs (Fritz, 2018).

The predilection of reporting SDGs is as a non-financial information, under a number of labels, frequently: Sustainability Report, Corporate Responsibility Report, Integrated Report, CSR Report, Non-financial Performance Statement, for the reason that the multidimensional structure of SDGs is analogous with nonfinancial reporting, which includes information about economic performance, environmental and social impact, health matters, demonstrating the link between corporate strategy and commitment to a sustainable global economy (EU, 2019).

Following several attempts to increase the relevance, consistency, transparency and comparability of the disclosure of non-financial information by European Union (EU) companies, the European Union decided to make mandatory the disclosure of non-financial information provided by large companies and groups publishing in 2014 the Non-Financial Reporting Directive (Directive 2014/95/EU) (NFR Directive). Accordingly, this Directive represents an important regulatory action towards harmonizing the non-financial reporting practices of all European Member 
States and marks the shift in non-financial reporting from a voluntary implementation to one that is mandatory for largest EU companies (La Torre et al., 2018).

The Directive advocates rules about the reporting of non-financial information applicable to the relevant companies beginning on $1^{\text {st }}$ January 2017 , or during the calendar year 2017. The non-financial statement should contain information necessary to understand the business's growth and development, position and performance, the impact of company's operations on social, environmental and employees, respect for human rights, fight against corruption and bribery, by including: a brief description of the business model of the company; a description of the company's policies and practice in relation to these issues; the outcome of these policies and practice; the key risks related to these issues, and the operation of the company; key non-financial performance indicators refer to the certain business. The impact on non-financial performance appears to be strictly interconnected to financial performance (the 'connectivity' of the six capitals of integrated reporting), as the achievement of the objectives of each dimension favours the achievement of positive results in the others Consequently, financial objectives must be combined synergistically with socio-environmental objectives (de Nuccio, 2020). In this way, profit becomes the expression of a superior ability to satisfy the expectations of all business partners, which, in turn, generates stakeholder approval, producing trust, cohesion and motivation, increased competitiveness and, from a circular point of view, contributes to improve financial results. The NFI Directive requirements reflect businesses complexity and ensure companies and their stakeholders have the information they need to make more informed decisions. The NFR Directive incorporates the most used frameworks and standards: Global Reporting Initiative (GRI) Standards, the integrated reportin framework (IR), Taskforce on Climate-related Financial Disclosure (TCFD) Recommendations, and Sustainable Development Goals Disclosure (SDGD) (de Nuccio, 2020).

However, research papers focused on non-financial reporting in CEE countries (Estonia, Hungary, Slovakia, Poland, Lithuania, Latvia, Croatia, Slovenia, Czech Republic, Bulgaria, Romania) disclose a gradual improvement and a clearly positive trend for the future (Accountancy Europe, 2020; Ariano \& Hategan, 2019; Dumitru et al., 2017; Putter, 2017; Raszkowski \& Bartniczak, 2019). The general trend is one of growth (up 3\%), but the divergence between Western and Eastern Europe observed in 2015 and 2017 remains. The rate of reporting in Eastern Europe is still relatively low at $65 \%$, despite an increase of $4 \%$ since 2015 . Eastern European countries may be closing the gap on the rest of the region but are doing so slowly as shown in Table 1. Clearly, the impact of the NFR Directive has yet to be fully felt (KPMG, 2017). 
Reporting on Sustainable Development Goals. A score-based approach with companylevel evidence from Central-Eastern Europe economies

Table 1. Corporate Responsibility reporting rates: Western Europe vs Eastern Europe

\begin{tabular}{|c|c|c|}
\hline Region & 2015 & 2017 \\
\hline Western Europe & $79 \%$ & $82 \%$ \\
\hline Eastern Europe & $61 \%$ & $65 \%$ \\
\hline
\end{tabular}

(Source: KPMG, 2017)

Many businesses in Eastern Europe are still focused on the financial bottom line rather than the triple bottom line - it is fair to say that a culture of sustainability is yet to properly take hold across the region, as shown in Table 2 .

Table 2. Corporate Responsibility reporting rates by countries

\begin{tabular}{|c|c|c|c|}
\hline Country & 2015 & 2017 & KPMG's remark \\
\hline $\begin{array}{l}\text { Czech } \\
\text { Republic }\end{array}$ & $\mathrm{N} / \mathrm{A}^{*}$ & $\mathrm{~N} / \mathrm{A}^{*}$ & $\mathrm{~N} / \mathrm{A}^{*}$ \\
\hline Hungary & $84 \%$ & $77 \%$ & $\begin{array}{l}\text { Countries with Corporate Responsibility (CR) } \\
\text { reporting rate higher than the global average } \\
(72 \%-89 \%)\end{array}$ \\
\hline Poland & $54 \%$ & $59 \%$ & $\begin{array}{l}\text { Countries with Corporate Responsibility (CR) } \\
\text { reporting rate lower than the global average (less } \\
\text { than } 72 \% \text { ) }\end{array}$ \\
\hline Romania & $68 \%$ & $74 \%$ & $\begin{array}{l}\text { Countries with Corporate Responsibility (CR) } \\
\text { reporting rate higher than the global average } \\
(72 \%-89 \%)\end{array}$ \\
\hline Slovakia & $48 \%$ & $55 \%$ & $\begin{array}{l}\text { Countries with Corporate Responsibility (CR) } \\
\text { reporting rate lower than the global average (less } \\
\text { than } 72 \% \text { ) }\end{array}$ \\
\hline
\end{tabular}

An informative non-financial report should include both positive and negative impact on the surroundings where the company is based, the company's environmental and social data, and the relationship to sustainable development.

Subsequently the fall or the decline of their non-democratic regimes, the economies of countries in Central and Eastern Europe (CEE) have significantly advanced, and improved reporting by companies is required and supported by international and regional organizations, as well as driven more or less successfully by local bodies (Albu et al., 2016).

For corporations operating in countries from CEE region, academic research papers highlight the reduced quality of non-financial reporting: Guse et al. (2016)'s research is revealing that a limited number of Romanian companies reports key performance indicators (KPIs) for non-financial disclosures and Turturea (2016) is 
ascertaining the concerns of Romanian listed companies about environmental and social disclosures in their reporting practices during 2001-2014, but limited to philanthropic activities; Kasparova (2018) and Sedlacek (2020) analysed the reports of corporations from Czech Republic and concluded that in the their reports, the non-financial information is very general and narrative and indicators such as the environmental impact of business, respect for human rights, philanthropy or anti-corruption rules and transparency were reported by only $43 \%$ of the 100 largest listed corporations; Matuszak and Razanska (2017) are noticing that Polish-listed companies are especially interested in reporting their environmental issues and still have a considerable amount of work to do in order to improve the level of reporting in the area of human rights, emphasizing the unbalanced reporting among themes of non-financial information. Similar results were obtained by Ienciu et al. (2011) when investigating the quality of environmental information voluntarily reported by Romanian listed companies compared with Hungarian companies for the period 2006-2008, concluding that the majority of environmental information provided by the Romanian companies is incomplete and irrelevant.

When discussing the reporting across industries, Dumitru et al. (2011) found a significant correlation between the degree of transparency of corporate responsibility disclosure and the industry sector displaying that Romanian companies operating in non-financial business communicate more CSR information as compared to financial services firms, similar with findings of Sedlacek (2020) for Czech manufacturing corporations and Matuszak and Rozanska (2017) and EY (2017) for Polish non-banking corporations.

Companies might mention the SDGs in their reporting, but have not yet developed any targets or KPIs for assessing and communicating their contributions to these goals (Guse et al., 2016; Schramade, 2017), and, as EY (2017) emphases, KPIs for the SDGs are still quite rare. Structured and unstructured communications, both online and offline, should disclose how the company intends to measure its contributions to the SDGs and what SDG-related performance goals it is aiming to. Setting goals demonstrates that the corporate is serious about growing business value by meeting global needs and can strengthen relationships with business partners such as customers and suppliers (KPMG, 2020). The Sustainable Development Goals Disclosure (SDGD) Recommendations encourage innovation in terms of disclosing performance. Although metrics are an essential part of assessing performance, narrative disclosures will be required to ensure reporting's completeness (Adams, 2020; Adams et al., 2020). Though it may be tempting to choose KPIs from those that happen to be currently available for other sustainability targets, KPIs really need to follow from goals rather than the other way around (Schramade, 2017). At business level, studies piloted by PwC (2018, 2019) suggest that, despite the SDGs being part of global business conversations 
and a significant number of companies guaranteeing a commitment to the Goals, there remains a gap between companies' good intentions and their ability to implement the SDGs into actual business strategy.

Generally, companies operating in CEE countries are engaged in non-financial reporting driven by brand reputation, economic consideration, market image and strengthen the relationship with stakeholders (Cetindamar \& Husoy, 2007; Joyner \& Payne, 2002; Kornieieva, 2020; KPMG,2011), and they register progress in corporate responsibility reporting and practices, making clear the interest in this area highly appreciated by clients, investors, and other stakeholders (Diaconu, 2012; Dyczkowska et al., 2016; EY, 2018; Jindrichovska \& Purcărea, 2011, Sedlacek, 2020; Tiron-Tudor et al., 2019; Raszkowski \& Bartniczak, 2019). Rosati and Faria (2019) draw attention on fact that organizations located in countries characterized by a greater focus on achieving quick results - short-term orientation - (particularly, the case of Hungary, Poland, Romania where the Hofstede's cultural dimension "long term orientation" is very low, less than 50 out of 100 (Hofstede et al., 2010)) might have been more prone to addressing the SDGs in their sustainability reports earlier.

To conclude, although it is encouraging to see more and more companies discussing the SDGs, for most of companies that is as far as it goes, and their management hardly admit that they are still in the exploration phase. They might mention the SDGs in their reporting, but they have not yet developed any targets or KPIs for assessing and communicating their contributions to SDGs (Schramade, 2017) and the presentation of SDGs in non-financial reports is very customized, and, frequently, unstructured and elusive. This communication on social, environmental and economic issues is in a stand-alone report or is part of an annual report, inside or outside of the audited financial statements and/or inside or outside of the management discussion and analysis and it is found in diverse forms of statements as print advertisements, press releases, securities filings, employee newsletters, and corporate websites (Băleanu et al., 2011; Eccles et al., 2012; Eccles \& Krzus, 2010; Fasan, 2013; Izzo et al., 2020; Rolland \& Bazzoni, 2009; Zeghal \& Ahmed, 1990).

\subsection{Role of accountancy profession in reporting SDGs}

In terms of reporting the SDGs, accountants will play a dynamic role in ensuring data is reliable and communicated effectively so that it can be used to support the disclosure of the SDGs. Better data will be a critical driver of the SDGs, therefore accounting professionals will be the upholders of this data (ACCA, 2017) and they will become notable advisors in the decision-making process. The specific professional skills of accountants - including in governance, risk management and 
controlling business analysis, as well as decision support, which involves measuring, reporting and providing assurance on financial and nonfinancial data will be increasingly in demand as the SDGs gain power (CGMA, 2018). Accountants possess a unique ability to help identify, capture, analyse, and communicate information critical in linking strategy and sustainability activities (Kaplan \& Norton, 2004; Epstein \& Hanson, 2006).

At this time, the accounting profession cannot disregard non-financial topics: environment social, governance, ethics and the role of accountants on how they can improve the business strategy and performance draw attention of numerous researchers (Ballou et al., 2011; Beattie, 2014; Bebbington, 2007; Bebbington \& Larrinaga, 2014; Bebbington \& Unerman, 2018; Brunelli \& Ranalli, 2020; Burchell et al., 1980; Gray, 2010; Gray \& Collison, 2002; Nechita, 2019; Schaltegger et al., 2017). The interest of accountancy profession in contributing to the reporting of holistic performance of corporations is noticeable as Oprisor (2015) emphasizes in his research when investigating the comment on Framework for Integrated Reporting, in respect to the principle-based requirements; assurance; the "business model" and "outcomes" definitions; the six capitals and materiality principle; the implementation perspective for non-profit organizations and public sector entities. Nowadays, the accountants have to reveal how the company's activities influence the level of environmental pollution, usage of non-renewable resources, public security, health and education, civil rights, and many other aspects of social life. Therefore, according to Jaglinska (1984), it is necessary to create a system of internal and external reporting in order to inform all stakeholders about all aspects and results of corporate activity (as cite by Waniak-Michalak, 2016).

According to IFAC (2016) and Gould and Lim (2019), at least 8 from a total of 17 SDGs have direct relation to accounting. The roles of professional accountants in sustainable reporting are: creators of value through development and implementation of strategies, policies, plans, structure and activities of the management and set a course to create sustainable development values (ACCA, 2017; IFAC, 2016; CGMA, 2018; Makarenko \& Plastun, 2017); providers of value by preparing high-quality reporting with prospects focus which is the basis of the sustainable development strategy (Fonseca \& Carvalho, 2019; IFAC, 2016; Rezaee \& Tuo, 2017); keepers of the value by defending natural, social, industrial and financial capital of the company (Bebbington \& Unerman, 2018, IFAC, 2016; Haller, 2016; Jindrichovska \& Purcărea, 2011); reporters of values by preparing and ensuring high-quality reporting for stakeholders (CGMA, 2018; CGMA, 2018; IFAC, 2016; Makarenko \& Plastun, 2017); educators of sustainability values (Albu et al., 2011; Bebbington \& Unerman, 2018, Firmansyah, 2019). 
In the paper of Ngwakwe (2012) we distinguish a critical examination of sustainable development initiatives in the accounting profession and the ambition for more a pragmatic approach to achieve accounting impact on sustainable development to overcome the contemporary state of sustainability reporting assessed as a week approximation of triple bottom line. For the new generation of accountant is important to create and develop sustainability competences $(\mathrm{Ng}$ et al., 2017) to endorse and uphold an enhanced SDG reporting.

The exploration of academic literature in respect to the disclosure and communication of SDGs by companies illustrates a limited number of research papers regarding the implementation and reporting of the SDGs by businesses operating in CEE countries and the involvements of accountants in improving SDGs reporting. Therefore, the research question of the current investigation is to assess the level of SDG's presence in corporates' reports published by companies operating in chemical industry, geographically located in Czech Republic (CZ), Hungary (HU), Poland (PL), Romania (RO), and Slovakia (SK) covering the period 2015 - 2019, and to establish the companies' advancement in achieving the SDGs reporting.

\section{Research methodology}

Since 2015, countries around the world have been translating the SDGs into national plans and policies, designing national implementation and monitoring strategies that would help combat the critical environmental, political, and economic challenges our world is facing. Appendix 1 discloses the list of SDGs as established by the UN in 2015. Achieving the sustainable development goals should be a concern for everyone, from civil society to governments and to business. This study aims to provide an assessment of the contribution, as well as to measure the progress made in this direction by chemical sector companies from representative countries geographically located in Central - Eastern Europe.

As previously emphasised, the academic and professional literature is rich in studies dealing with sustainable development. However, to our knowledge, the majority of such studies approach a macroeconomic, country level analysis (McArthur \& Rasmussen, 2019; Nechita et al., 2020; OECD, 2019) and there are limited papers that quantify the impact on SDGs by applying a company-level, microeconomic analysis, and particularly focusing on companies from the chemical sector in CEE economies. The paper has several significant contributions. Firstly, it addresses and analyses the influence exerted on all SDGs, while most studies are considering only one or part of the SDGs (Balcerowicz-Szkutnik et al., 2020). Secondly, the study highlights both the SDGs that benefit from substantial efforts and those SDGs which require further attention, the analysis being conducted based on reports and data available on the companies' websites. Thirdly, the paper is 
focused on the chemical sector, which plays an important role serving as a supplier of products and services to practically every other industry - from food and clothes to technology. The chemical sector is heterogeneous and complex, one of the most diversified from all industries (Aga, 2012), and thus it interacts with an extensive number of SDGs (WBCSD, 2018).

\subsection{Selection criteria}

The analysis presented in this article covers the following five representative CEE countries: Czech Republic, Hungary, Poland, Romania, and Slovakia. We analysed the chemical industry because of its key role in maintaining growth and prosperity, and in transition to a sustainable society. The European Chemical sector comprises around 28,000 companies employing more than 1.4 million people and generating $1.1 \%$ of European Union (EU) GDP. The biggest customers of European chemicals are the rubber and plastics (14\%) and healthcare (11\%) sectors, but chemicals are part of products used every day in all areas: from technology in electrical devices, to cars, clothing, building materials and medicines (Cefic Sustainability Report, 2017). Table 3 shows the influence of the chemical sector in economy for each of the five analysed countries.

Table 3. Chemical sector influence on a country-level

\begin{tabular}{ll}
\hline $\begin{array}{l}\text { Country / } \\
\text { GDP 2019 }\end{array}$ & Chemical industry influence \\
\hline Czech Republic / & $\begin{array}{l}\text { Chemical industry plays a key role in the Czech economy, } \\
\text { 246,49 billion USD } \\
\text { being the second largest manufacturing industry in the Czech } \\
\text { Republic, after automotive industry (19,77 billion EUR } \\
\text { turnover, 1,851 companies and } 129,500 \text { direct employees in } \\
\text { 2018). }\end{array}$
\end{tabular}

Hungary / Hungary's chemical industry registered a growth rate above 170,41 billion USD the EU chemical industry average. The Hungarian chemical industry accounts for $6 \%$ of total manufacturing industry (5,4 billion EUR turnover, 15,039 direct employees in 2018).

Poland /

592,16 billion USD

The chemical industry has a very high position among industrial sectors. The share of chemical industry in the total industry is $17 \%$. The Polish chemical industry is developing dynamically, with a growth rate which is second among the world's largest economies $(62,15$ billion USD turnover, 315,000 direct employees, more than 11,000 companies).

Romania /

250 billion USD

Romania's chemical industry is smaller, but sizable $(2,3$ billion EUR turnover, 979 companies, 22,500 direct employees in 2016). 
Reporting on Sustainable Development Goals. A score-based approach with companylevel evidence from Central-Eastern Europe economies

\begin{tabular}{ll}
\hline $\begin{array}{l}\text { Country / } \\
\text { GDP 2019 }\end{array}$ & Chemical industry influence \\
\hline Slovakia / & $\begin{array}{l}\text { The Slovak chemical industry has traditionally been one of } \\
\text { the largest sectors of the national economy. In 2014, the } \\
\text { chemical companies generated almost } 12 \% \text { of the Slovak } \\
\text { industry (10,3 billion EUR turnover, 307 companies and } \\
46,143 \text { direct employees in 2018). }\end{array}$
\end{tabular}

(Source: https://data.worldbank.org/, https://www.chemlandscape.cefic.org/)

Using the ISI Emerging Markets Group's EMIS platform database for companies, we selected the first ten companies sorted by operating revenue for each country, because Top leaders based methodology is considered a leading practice in SustainAbility (Albu et al., 2013). The strategy for identifying relevant reporting data continued with searching the reports and website information for each company and deciding on inclusion and exclusion criteria for constructing the appropriate database.

The inclusion criteria for this study are:

- focus on all sustainable development goals;

- a five-year period: 2015-2019 - as the SDGs were set by the United Nations General Assembly in 2015;

- all types of reports - non-financial reports such as Sustainability / Social Responsibility / Social Impact Reports or annual reports with non-financial information to the extent that the formers were not available;

- individual or group reporting - the group reporting information was used when the individual reports were not available;

- additional information from companies' websites, if case (when reports were not available or when the information provided on the website covered complementary aspects).

We applied exclusion criteria to ensure a greater quality of research data, namely for:

- non-available / missing information;

- non-English language reports - to avoid biases associated with language.

Subsequently applying the mentioned criteria, from the initial sample consisting of 50 companies (top 10 firms based on their operating revenues for each of the 5 selected countries), only 35 firms were left, adding up to a number of 114 firm-year observations (from 111 reports and 3 observations based on website only). We hand-collected companies' reports and additional information from the firms' websites. 


\subsection{Data collection instruments and procedures}

Through the responsible production, use, and management of chemicals, the chemical sector can contribute to achieving the SDGs using innovative products and practices that minimize any adverse aspects while maximizing positive impacts.

In order to assess the extent to which the chemical sector companies engaged in and reported SDG's achievements, we developed and applied a score-based approach using a scale from 0 to 5 , taking into account the targets, the efforts and the measurements companies have set and have monitored during the analysed period, as shown in Table 4 and detailed in Appendix 2. A similar scoring methodology was applied by Hummel (2019), Ionaşcu et al. (2020), Matuszak and Razanska (2017) and PwC (2018).

Table 4. SDG Scoring Methodology

\begin{tabular}{|c|c|c|c|}
\hline Score & Targets & $\begin{array}{l}\text { Measure } \\
\text {-ments }\end{array}$ & Description \\
\hline 0 & - & - & $\begin{array}{l}\text { No information disclosed in respect to a specific } \\
\text { goal / no target to accomplish }\end{array}$ \\
\hline 1 & Tc & - & $\begin{array}{l}\text { SDG with qualitative target, but no results } \\
\text { measured and reported yet: there is a qualitative } \\
\text { ambition for the company (i.e. narrative } \\
\text { description about company plans to take action } \\
\text { on those targets), but no information about } \\
\text { reporting any obtained results on the progress } \\
\text { towards the SDG target. }\end{array}$ \\
\hline 2 & $\mathrm{Tc}+\mathrm{Eq}$ & - & $\begin{array}{l}\text { SDG with qualitative target and quantitative } \\
\text { efforts invested, but no results measured and } \\
\text { reported yet: there is a qualitative ambition for } \\
\text { the company (i.e. narrative description about } \\
\text { company plans to take action on those targets) } \\
\text { and investments were made, but no information } \\
\text { about reporting any obtained results on the } \\
\text { progress towards the SDG target. }\end{array}$ \\
\hline 2 & $\mathrm{Tq}$ & - & $\begin{array}{l}\text { SDG with quantitative target, but no results } \\
\text { measured and reported yet: there is a quantitative } \\
\text { ambition for the company (i.e. company has set } \\
\text { quantified measures that it is aiming for in the } \\
\text { future), but no information about reporting any } \\
\text { obtained results on the progress towards the SDG } \\
\text { target. }\end{array}$ \\
\hline
\end{tabular}


Reporting on Sustainable Development Goals. A score-based approach with companylevel evidence from Central-Eastern Europe economies

\begin{tabular}{|c|c|c|c|}
\hline Score & Targets & $\begin{array}{l}\text { Measure } \\
\text {-ments }\end{array}$ & Description \\
\hline 3 & $\mathrm{Tc}$ & $\mathrm{Mc}$ & $\begin{array}{l}\text { SDG with qualitative target and qualitative } \\
\text { measurement of the result(s) reported on the } \\
\text { progress: there is a qualitative ambition for the } \\
\text { company (i.e. narrative description about } \\
\text { company plans to take action on those targets) } \\
\text { and a qualitative assessment of the obtained } \\
\text { results on the progress towards the SDG target is } \\
\text { disclosed (i.e. narrative description of the effects } \\
\text { of those actions). }\end{array}$ \\
\hline 4 & $\mathrm{Tc}$ & $\mathrm{Mq}$ & $\begin{array}{l}\text { SDG with qualitative target and quantitative } \\
\text { measurement of the result(s) reported on the } \\
\text { progress: there is a qualitative ambition for the } \\
\text { company (i.e. narrative description about } \\
\text { company plans to take action on those targets) } \\
\text { and a quantitative assessment of the obtained } \\
\text { results on the progress towards the SDG target is } \\
\text { disclosed. }\end{array}$ \\
\hline 5 & $\mathrm{Tq}$ & $\mathrm{Mc}$ & $\begin{array}{l}\text { SDG with quantitative target and qualitative } \\
\text { measurement of the result(s) reported on the } \\
\text { progress: there is a quantitative ambition for the } \\
\text { company and a qualitative assessment of the } \\
\text { obtained results on the progress towards the SDG } \\
\text { target is disclosed (i.e. narrative description of } \\
\text { the effects of those actions). }\end{array}$ \\
\hline 5 & $\mathrm{Tq}$ & $\mathrm{Mq}$ & $\begin{array}{l}\text { SDG with quantitative target and quantitative } \\
\text { measurement of the result(s) reported on the } \\
\text { progress: there is a quantitative ambition for the } \\
\text { company and a quantitative assessment of the } \\
\text { obtained results on the progress towards the SDG } \\
\text { target is disclosed. }\end{array}$ \\
\hline
\end{tabular}

Where:

Tc Qualitative target

Tq Quantitative target

Eq Quantitative effort invested

Mc Qualitative measurement of the result

$\mathrm{Mq} \quad$ Quantitative measurement of the result

We considered a distinction between qualitative and quantitative aspects reported by companies. This was necessary because it provides useful information regarding the extent to which the concept of sustainable development is being implemented (Raszkowski \& Bartniczak, 2019). Setting quantitative targets and monitoring their 
achievements reflect the effective practices that companies have applied in implementing the SDGs.

\subsection{Analysis methods}

We conducted a textual and content analysis of the reports and other information available on the companies' websites in order to assess the score for each sustainable development goal. Similar to Hummel (2019), Khan et al. (2018), and Nichita (2018), we screened all accessible reports in full to identify the qualitative and quantitative targets, efforts, or measurements for each SDG. We used the textual analysis (Hummel, 2019; Li, 2010) in order to determine whether the companies address the SDGs in their reports, by applying search queries for the occurrence of key words, such as "sustainable", "sustainability", "SDG". Afterwards, we applied a content analysis (Guthrie \& Abeysekera, 2006; Guthrie \& Parker, 2006; Khan et al., 2018; Lungu et al., 2011) for the assessment of the score. All team members were involved in the data collection process and at least two members carefully monitored, and cross-validated the information gathered, paying special attention to particular cases in order to ensure the quality, comparability, and reliability of the research.

We assigned a score for each firm-year observation by judging the company's contribution to each SDG, based on the reported information. Therefore, we attributed the score to a sustainable development goal either by allocating it based on targets and actions addressing or influencing that particular SDG, or by considering the clearly specified SDGs in the reports. Moreover, when an SDG was targeted by the firm, we assigned a score to it if at least one indicator addressing that SDG was influenced by the company.

The conducted research was based on the analysis of all the SDGs, nevertheless a deeper analysis was undertaken to reveal the implementation of the $10+1$ goals that were identified as being priority SDGs for the chemical sector (WBCSD, 2018), as follows:

- SDG 2 Zero hunger;

- SDG 3 Good health and well-being;

- SDG 6 Clean water and sanitation;

- SDG 7 Affordable and clean energy;

- SDG 8 Decent work and economic growth;

- SDG 9 Industry, innovation and infrastructure;

- SDG 11 Sustainable cities and communities;

- SDG 12 Responsible consumption and production;

- SDG 13 Climate action;

- SDG 14 Life below water; 
Reporting on Sustainable Development Goals. A score-based approach with companylevel evidence from Central-Eastern Europe economies

- SDG 17 Partnership for the goals - not specifically identified as a priority goal, but it is included considering the spirit of collaboration that it embodies, and thus interact with the entire SDG agenda.

\section{Results}

Our research conducted to noteworthy results and will contribute to enhance investigations concerning understanding of the complex interrelationships which influence the ability of companies to create value to stakeholders and to support creation of a better world. Outcomes found in this paper highlight similitudes, differences, and nuances in disclosing SDGs by companies operating in chemical sector.

\subsection{Results and descriptive discussion related to SDGs reporting}

\subsubsection{Structure of the sample}

In terms of the sample structure per year, company and country, Table 5 emphasises an increasing number of reports in the years following the SDGs issuance, starting from a total number of 17 reports in 2015, and continuing with 22 reports in 2016, 25 in 2017 and then 26 in 2017. This positive trend is partially disrupted in 2019, when the number of reports either stagnated of slightly decreased for each country, as well as decreased to a total number of 21 reports overall. The later evolution could also be a consequence of a delay in preparing the reports for 2019, as the publication date for this type of reports might differ from the one of the annual reports. Despite this drawback, the overall number in 2019 is still higher than the one registered for 2015 (by 24\%). Hence, developing the SDGs in 2015 positively influenced the companies' interest in sustainability reporting, at least by providing a better understanding on the concept of sustainable development and by drawing an agenda of the following steps to be applied towards building a better world.

Regarding the type of reporting, out of the 114 observations included in the sample, $63 \%$ of the analysed reports did not mention the specific SDGs their efforts were targeting. The highest percentage obtained by this category of reports, for which the SDG score was allocated based on the interpretation of the targets, efforts and measurements disclosed, is partially explained by the fact that in 2015 the SDGs have just been released. Therefore, their novelty degree might have represented an impediment in reporting. A number of 32 observations, representing $28 \%$ of the sample were based on the SDGs clearly specified in the reports, whereas the remaining 9\% (10 observations) consisted in both allocated SDGs and particularly mentioned ones. 
Table 5. Structure of the sample on countries and firm-year observations (based on the number of reports)

\begin{tabular}{cccccccccc}
\hline Country & $\mathbf{2 0 1 5}$ & $\mathbf{2 0 1 6}$ & $\mathbf{2 0 1 7}$ & $\mathbf{2 0 1 8}$ & $\mathbf{2 0 1 9}$ & Min & Max & Mean & Total \\
\hline CZ & 3 & 3 & 4 & 4 & 4 & 3 & 4 & 3.6 & $\mathbf{1 8}$ \\
HU & 1 & 2 & 4 & 5 & 3 & 1 & 5 & 3.0 & $\mathbf{1 5}$ \\
PL & 4 & 6 & 6 & 6 & 5 & 4 & 6 & 5.4 & $\mathbf{2 7}$ \\
RO & 3 & 3 & 5 & 5 & 3 & 3 & 5 & 3.8 & $\mathbf{1 9}$ \\
SK & 6 & 8 & 6 & 6 & 6 & 6 & 8 & 6.4 & $\mathbf{3 2}$ \\
\hline Overall number & $\mathbf{1 7}$ & $\mathbf{2 2}$ & $\mathbf{2 5}$ & $\mathbf{2 6}$ & $\mathbf{2 1}$ & & & & $\mathbf{1 1 1}$ \\
\hline
\end{tabular}

This structure might be influenced by the reporting framework companies apply in disclosing sustainability issues, as there are at least 230 initiatives on corporate sustainability standards in over 80 sectors of activity worldwide. The commonly used sustainability reporting frameworks being the Global Reporting Initiative (GRI) and the United Nations Global Compact (UNGC) (Nechita, 2019), this also being the case of our sample.

\subsubsection{Descriptive statistics}

Table 6 comprises descriptive statistics for each SDG identified in reports issued by selected companies and highlights the overall SDGs score for the period 20152019, with additional details regarding the average SDG score values shown in Appendix 2.

Table 6. Descriptive statistics

\begin{tabular}{lrrrrr}
\hline SDG & Mean & $\begin{array}{c}\text { Standard } \\
\text { deviation }\end{array}$ & Variance & Score & $\begin{array}{l}\text { Observations } \\
(\mathbf{N})\end{array}$ \\
\hline SDG 1 & 0.7193 & 1.3338 & 1.7789 & 82 & 114 \\
SDG 2 & 0.6491 & 1.3034 & 1.6988 & 74 & 114 \\
SDG 3 & 3.0175 & 1.9186 & 3.6811 & 344 & 114 \\
SDG 4 & 3.2807 & 1.4785 & 2.1860 & 374 & 114 \\
SDG 5 & 2.7105 & 2.0164 & 4.0659 & 309 & 114 \\
SDG 6 & 3.6053 & 1.6489 & 2.7189 & 411 & 114 \\
SDG 7 & 3.5614 & 1.5743 & 2.4785 & 406 & 114 \\
SDG 8 & 4.0526 & 1.3227 & 1.7494 & 462 & 114 \\
SDG 9 & 3.2719 & 1.6036 & 2.5714 & 373 & 114 \\
SDG 10 & 1.6228 & 1.7569 & 3.0866 & 185 & 114 \\
SDG 11 & 2.6754 & 1.6102 & 2.5928 & 305 & 114 \\
SDG 12 & 3.7456 & 1.4803 & 2.1914 & 427 & 114
\end{tabular}


Reporting on Sustainable Development Goals. A score-based approach with companylevel evidence from Central-Eastern Europe economies

\begin{tabular}{lrrrrr}
\hline SDG & Mean & $\begin{array}{c}\text { Standard } \\
\text { deviation }\end{array}$ & Variance & Score & $\begin{array}{l}\text { Observations } \\
\text { (N) }\end{array}$ \\
\hline SDG 13 & 3.7719 & 1.4019 & 1.9652 & 430 & 114 \\
SDG 14 & 1.0439 & 1.6953 & 2.8742 & 119 & 114 \\
SDG 15 & 1.7719 & 1.9689 & 3.8767 & 202 & 114 \\
SDG 16 & 1.1316 & 1.8120 & 3.2834 & 129 & 114 \\
SDG 17 & 3.5000 & 1.5867 & 2.5177 & 399 & 114 \\
\hline
\end{tabular}

As indicated in Table 6, the highest overall SDG score was obtained for SDG 8, adding up to a value of 462 out of a maximum of 875 , emphasising that companies are mostly concerned about the safety and well-being of their employees, correspondingly considering that most reports highlighted that companies recorded no fatalities or work accidents.

The SDGs running up next are related to climate action (SDG 13) with a score of 430 and responsible consumption and production (SDG 12), with a score of 427, these findings being consistent with our expectations, given the characteristics and specifics of the chemical industry. Therefore, companies prioritize mitigating the impact of their activities on the environment, especially by taking actions in decreasing the gas emissions. Similar interest is shown for waste management and recycling. These two key SDGs are strongly correlated with the firms' investments in innovation and new technologies (SDG 9 scoring a significant level of 373), as well as the companies' engagement in various partnerships with governmental institutions (SDG 17 scoring 399, likewise being situated above the average).

SDG 3 Good health and well-being (Score 344), SDG 4 Quality education (Score 374), SDG 5 Gender equality (Score 309) and SDG 7 Affordable and clean energy (Score 406) are other goals that recorded a Score above the mean. This is explained by the companies' involvement in public health actions (many firms reported their employees volunteering in blood donation programs), by providing internships and holding lectures in partnership with local universities, by encouraging women and monitoring the employees structure on gender (including for leadership positions), as well as implementing measures for the decrease of energy consumption or developing innovative technology for the production of renewable energy.

On the other hand, the low-scoring goals are represented by SDG 15 (Score 202), SDG 10 (Score 185) and SDG 16 (Score 129), located below the mean, whereas SDG 14 (Score 119), SDG 1 (Score 82) and SDG 2 (Score 74) are situated at the end of the range. While measures taken for improving life on land and increasing biodiversity, as well as the ones dedicated to reducing inequalities were in some ways expected (although having a smaller impact than others), the companies' 
contribution to peace, justice and strong institutions came as a positive surprise, as a significant number of firms reported their involvement in anti-bribery actions.

The standard deviation disclosed in Table 6 shows no significant variation, observations mostly being spread out in range of the central tendency. SDG 5 registers the highest standard deviation, whereas SDG 2 records the lowest one. This is explained by the fact that the actions reported by firms on gender equality led to either assigning a high score, where this aspect was considered, or the lowest score in the case there was no mention of gender analysis in their reports. In terms of the zero-hunger score, the lowest standard deviation is a result of the high number of observations assigned with a null or close to 0 score for this goal.

\subsection{Analysis of the average score by companies and the completion percentage on average}

From the total number of 35 companies included in the sample, 12 companies (34.28\%) record an average SDG score situated above the mean of 44.13, as presented in Appendix 3. The analysis based on SDGs completion percentage on average revealed several important aspects. On one hand, four companies representing $11 \%$ of the analysed sample succeeded to achieve a SDGs completion percentage on average that exceeded $70 \%$, while 5 companies obtained completion percentage score less than $30 \%$ (as illustrated in Table 7).

Table 7. SDGs completion as percentage on average and average number of SDGs reported

\begin{tabular}{lcc}
\hline Company & $\begin{array}{l}\text { SDGs completion } \\
\text { percentage } \\
\text { on average }\end{array}$ & $\begin{array}{l}\text { Average } \\
\text { number of SDGs } \\
\text { reported }\end{array}$ \\
\hline AZOMURES SA - AMEROPA GROUP & $52 \%$ & 13 \\
BASF SLOVENSKO SPOL. S R.O. & $64 \%$ & 13 \\
BORSODCHEM ZRT. & $51 \%$ & 12 \\
BORYSZEW S.A & $29 \%$ & 12 \\
CHINOIN ZRT. (SANOFI GROUP) & $59 \%$ & 13 \\
CIECH GROUP & $32 \%$ & 13 \\
COLAS CZ A.S. & $55 \%$ & 13 \\
DE MICLEN A.S. - GSK GROUP & $66 \%$ & 15 \\
DEZA A.S. & $22 \%$ & 7 \\
DUSLO, A.S. & $32 \%$ & 8 \\
ENAGRO, A.S. - ENVIEN GROUP & $2 \%$ & 2 \\
FORTISCHEM A.S. & $13 \%$ & 6 \\
GEDEON RICHTER NYRT. & $35 \%$ & 9 \\
GRUPA AZOTY GROUP & $41 \%$ & 16 \\
\hline
\end{tabular}

Vol. 19, No. 3 
Reporting on Sustainable Development Goals. A score-based approach with companylevel evidence from Central-Eastern Europe economies

\begin{tabular}{|c|c|c|}
\hline Company & $\begin{array}{l}\text { SDGs completion } \\
\text { percentage } \\
\text { on average }\end{array}$ & $\begin{array}{l}\text { Average } \\
\text { number of SDGs } \\
\text { reported }\end{array}$ \\
\hline HANKOOK TIRE MAGYARORSZAG KFT & $51 \%$ & 12 \\
\hline HARTMANN - RICO A.S. & $9 \%$ & 5 \\
\hline HENKEL SLOVENSKO, SPOL. S. R.O. & $84 \%$ & 17 \\
\hline JOHNSON \& JOHNSON, S.R.O. & $79 \%$ & 16 \\
\hline KRKA D.D. & $44 \%$ & 13 \\
\hline LINDE GAS A.S. & $93 \%$ & 17 \\
\hline MOL PETROLKEMIA ZRT. & $51 \%$ & 12 \\
\hline NOVARTIS SLOVAKIA S.R.O. & $81 \%$ & 17 \\
\hline OLTCHIM SA & $27 \%$ & 9 \\
\hline PHOENIX PHARMA ZRT. & $44 \%$ & 10 \\
\hline ROMPETROL RAFINARE SA & $69 \%$ & 17 \\
\hline SILON S.R.O. & $14 \%$ & 5 \\
\hline SLOVNAFT, A.S. & $48 \%$ & 12 \\
\hline SOPHARMA AD & $31 \%$ & 17 \\
\hline $\begin{array}{l}\text { SUN PHARMACEUTICAL INDUSTRIES } \\
\text { LTD. (TERAPIA SA) }\end{array}$ & $40 \%$ & 12 \\
\hline SYNTHOS DWORY 7 SP. Z O.O. SP. J. & $34 \%$ & 13 \\
\hline $\begin{array}{l}\text { TEVA CZECH INDUSTRIES S.R.O. } \\
\text { UNILEVER SOUTH CENTRAL EUROPE }\end{array}$ & $63 \%$ & 14 \\
\hline SA & $62 \%$ & 14 \\
\hline $\begin{array}{l}\text { UNIPETROL GROUP } \\
\text { ZAKLADY FARMACEUTYCZNE }\end{array}$ & $45 \%$ & 15 \\
\hline $\begin{array}{l}\text { POLPHARMA S.A. } \\
\text { POLPATE }\end{array}$ & $50 \%$ & 13 \\
\hline ZENTIVA SA & $58 \%$ & 14 \\
\hline Mean & $46 \%$ & 12 \\
\hline
\end{tabular}

Grey colour shows values above the mean

We interpret these findings are not revealing a desirable situation considering that 5 years have already passed since the SDGs were set on global level and companies should have had enough time to manage the SDGs implementing and reporting procedures. On the other hand, it should be noticed that the average for the chemical sector is close to half (46\%). Considering the chemical sector completion percentage average, the analysis showed that 18 companies totalling $51 \%$ of the sample reported above average information on SGDs targets, efforts, and measurements.

Our results emphasized that there is an extraordinary symmetry for the first and last places in SDGs completion hierarchy, but also for the distribution of companies compared to the chemical sector average. Hence, $50 \%$ of the analysed companies 
improve their SDGs implementing and reporting procedure to achieve a high level in reporting hierarchy, while the other half should manage SDGs in a better way to ensure a position at least above average.

Findings shows that the chemical sector entities are focusing their efforts on average on 12 of the 17 SDGs (Table 7). A cluster of 5 of the companies, consisting in $14.28 \%$ of the sample, report on all the 17 SDGs (HENKEL SLOVENSKO, SPOL. S R.O., LINDE GAS A.S., NOVARTIS SLOVAKIA S.R.O., ROMPETROL RAFINARE S.A., and SOPHARMA AD), while other 5 firms are the lowest rankers by reporting only below 8 SDGs (DEZA AS, ENAGRO AS - ENVIEN GROUP, FORTISCHEM AS, HARTMANN - RICO A.S. and SILON S.R.O.). For the latter category, the result is also determined by the fact that information regarding sustainable development was available only briefly on the companies' websites or there was only 1 published report found containing limited data.

The goals which were most reported on are SDG 12, SDG 13, and SDG 17, which were mentioned by more than $90 \%$ of the companies, as shown in Table 8 . Goals 4 , $5,6,7$ and 8 appeared in $80-90 \%$ of the companies, while SDG 3, 9, 10 and 15 were allocated by $60-80 \%$ of the companies. The lowest ranks were occupied by SDG 1, SDG 14 and SDG 16 located between 37-40\%, respectively SDG 2 reported only by $29 \%$ of the companies. The ranking confirms our initial expectations and it is significantly determined by the relation between the chemical sector particularities and the specificity of each SDG. These results are consistent with our previous findings regarding the highest overall and average scores, and similar to the ones obtained by Ionașcu et al. (2020) for the real estate sector.

Table 8. Frequency of SDGs reported by the companies

\begin{tabular}{llllllllllllllllll}
\hline SDG & $\mathbf{1}$ & $\mathbf{2}$ & $\mathbf{3}$ & $\mathbf{4}$ & $\mathbf{5}$ & $\mathbf{6}$ & $\mathbf{7}$ & $\mathbf{8}$ & $\mathbf{9}$ & $\mathbf{1 0}$ & $\mathbf{1 1}$ & $\mathbf{1 2}$ & $\mathbf{1 3}$ & $\mathbf{1 4}$ & $\mathbf{1 5}$ & $\mathbf{1 6}$ & $\mathbf{1 7}$ \\
\hline $\begin{array}{c}\text { Frequency } \\
\text { (no.) }\end{array}$ & 14 & 10 & 26 & 31 & 28 & 30 & 29 & 31 & 31 & 22 & 27 & 32 & 34 & 13 & 22 & 13 & 33 \\
$\begin{array}{c}\text { Frequency } \\
(\%)\end{array}$ & 40 & 29 & 74 & 89 & 80 & 86 & 83 & 89 & 89 & 63 & 77 & 91 & 97 & 37 & 63 & 37 & 94 \\
\hline
\end{tabular}

\subsection{Analysis of the overall score by companies}

The highest score was obtained by LINDE GAS AS, although the company has reported the SDGs in only one year. By achieving this score, the company showed that it has great potential in both SDGs implementing and reporting, but it lacks consistency over the analysed period. There are other 10 companies which also have a single report, but their score did not exceed 43, meaning an implementing degree below $51 \%$. These companies are covering almost $29 \%$ of the companies' sample, but a trend in their reporting of SDGs cannot be established. 
Reporting on Sustainable Development Goals. A score-based approach with companylevel evidence from Central-Eastern Europe economies

Table 9. SDGs company score by year

\begin{tabular}{|c|c|c|c|c|c|}
\hline Company & $\begin{array}{l}\text { Score } \\
2015\end{array}$ & $\begin{array}{l}\text { Score } \\
2016\end{array}$ & $\begin{array}{l}\text { Score } \\
2017\end{array}$ & $\begin{array}{l}\text { Score } \\
2018\end{array}$ & $\begin{array}{l}\text { Score } \\
2019\end{array}$ \\
\hline AZOMURES SA - AMEROPA GROUP & 38 & 42 & 45 & 46 & 48 \\
\hline BASF SLOVENSKO SPOL. S R.O. & 48 & 48 & 51 & 62 & 65 \\
\hline BORSODCHEM ZRT. & 0 & 0 & 0 & 43 & 0 \\
\hline BORYSZEW S.A & 0 & 6 & 28 & 30 & 33 \\
\hline CHINOIN ZRT. (SANOFI GROUP) & 0 & 47 & 51 & 49 & 54 \\
\hline CIECH GROUP & 10 & 23 & 31 & 36 & 37 \\
\hline COLAS CZ A.S. & 52 & 38 & 38 & 52 & 52 \\
\hline DE MICLEN A.S. - GSK GROUP & 63 & 59 & 59 & 44 & 55 \\
\hline DEZA A.S. & 0 & 0 & 0 & 0 & 19 \\
\hline DUSLO, A.S. & 0 & 27 & 0 & 0 & 0 \\
\hline ENAGRO, A.S. - ENVIEN GROUP & 0 & 0 & 0 & 0 & 2 \\
\hline FORTISCHEM A.S. & 0 & 11 & 0 & 0 & 0 \\
\hline GEDEON RICHTER NYRT. & 0 & 0 & 30 & 0 & 0 \\
\hline GRUPA AZOTY GROUP & 22 & 32 & 35 & 42 & 44 \\
\hline $\begin{array}{l}\text { HANKOOK TIRE MAGYARORSZAG } \\
\text { KFT }\end{array}$ & 0 & 0 & 40 & 46 & 0 \\
\hline HARTMANN - RICO A.S. & 0 & 0 & 3 & 0 & 12 \\
\hline HENKEL SLOVENSKO, SPOL. S R.O. & 71 & 71 & 71 & 71 & 71 \\
\hline JOHNSON \& JOHNSON, S.R.O. & 67 & 66 & 67 & 67 & 67 \\
\hline KRKA D.D. & 36 & 37 & 38 & 38 & 39 \\
\hline LINDE GAS A.S. & 0 & 0 & 0 & 79 & 0 \\
\hline MOL PETROLKEMIA ZRT. & 38 & 44 & 44 & 44 & 45 \\
\hline NOVARTIS SLOVAKIA S.R.O. & 45 & 77 & 74 & 74 & 74 \\
\hline OLTCHIM S.A. & 0 & 0 & 29 & 17 & 0 \\
\hline PHOENIX PHARMA ZRT. & 0 & 0 & 0 & 37 & 37 \\
\hline ROMPETROL RAFINARE S.A. & 58 & 65 & 53 & 59 & 0 \\
\hline SILON S.R.O. & 0 & 0 & 0 & 0 & 12 \\
\hline SLOVNAFT, A.S. & 42 & 42 & 41 & 39 & 38 \\
\hline SOPHARMA AD & 26 & 23 & 32 & 29 & 22 \\
\hline $\begin{array}{l}\text { SUN PHARMACEUTICAL INDUSTRIES } \\
\text { LTD. (TERAPIA SA) }\end{array}$ & 0 & 0 & 0 & 0 & 34 \\
\hline SYNTHOS DWORY 7 SP. Z O.O. SP. J. & 0 & 0 & 29 & 0 & 0 \\
\hline TEVA CZECH INDUSTRIES S.R.O. & 57 & 56 & 55 & 45 & 53 \\
\hline $\begin{array}{l}\text { UNILEVER SOUTH CENTRAL EUROPE } \\
\text { SA }\end{array}$ & 44 & 44 & 56 & 60 & 60 \\
\hline UNIPETROL GROUP & 35 & 35 & 33 & 33 & 54 \\
\hline ZAKLADY FARMACEUTYCZNE & 0 & 44 & 0 & 41 & 0 \\
\hline
\end{tabular}




\begin{tabular}{lccccc}
\hline Company & $\begin{array}{l}\text { Score } \\
\mathbf{2 0 1 5}\end{array}$ & $\begin{array}{l}\text { Score } \\
\mathbf{2 0 1 6}\end{array}$ & $\begin{array}{l}\text { Score } \\
\mathbf{2 0 1 7}\end{array}$ & $\begin{array}{l}\text { Score } \\
\mathbf{2 0 1 8}\end{array}$ & $\begin{array}{l}\text { Score } \\
\mathbf{2 0 1 9}\end{array}$ \\
\hline POLPHARMA S.A. & & & & & \\
ZENTIVA SA & 0 & 0 & 52 & 47 & 0 \\
\hline
\end{tabular}

For the remaining companies (with more than 2 reports), we observed as Table 9 highlights, the followings aspects:

- 3 companies recorded high constant values showing their great interest related to SDGs reporting (HENKEL SLOVENSKO, SPOL. S.R.O., JOHNSON \& JOHNSON, S.R.O., NOVARTIS SLOVAKIA S.R.O.);

- 1 company obtained medium constant values (PHOENIX PHARMA ZRT.);

- for 11 companies a growing trend was observed; we assert this is a favourable situation as companies show their interest on improving their actions and reporting information related to SDGs (AZOMURES SA - AMEROPA GROUP, BASF SLOVENSKO SPOL. S R.O., BORSODCHEM ZRT., BORYSZEW S.A, CHINOIN ZRT. (SANOFI GROUP), GRUPA AZOTY GROUP, HANKOOK TIRE MAGYARORSZAG KFT, HARTMANN RICO A.S., KRKA D.D., MOL PETROLKEMIA ZRT., UNIPETROL GROUP);

- 6 companies have an oscillating trend over the analysed period (COLAS CZ A.S., DE MICLEN A.S. - GSK GROUP, ROMPETROL RAFINARE SA, SOPHARMA AD, TEVA CZECH INDUSTRIES S.R.O., UNIPETROL GROUP);

- only for 4 companies the analysis revealed a decreasing trend (OLTCHIM SA, SLOVNAFT, A.S., ZAKLADY FARMACEUTYCZNE POLPHARMA S.A., ZENTIVA SA).

The last two observations are unfavourable in terms of SDGs reporting and may be explained by changes made in the report format from one year to another.

\subsection{Analysis of SDGs score by years}

As shown in Table 10, the interest in reporting the SDGs achievements has an increasing trend in the first years from 2015 to 2018 , followed by a decrease in the last year for all the sustainable development goals.

Table 10. SDGs achievement rate over the analysed period

\begin{tabular}{|c|c|c|c|c|c|}
\hline SDG/Year & 2015 & 2016 & 2017 & 2018 & 2019 \\
\hline SDG 1 & $2 \%$ & $2 \%$ & $3 \%$ & $4 \%$ & $3 \%$ \\
\hline SDG 2 & $2 \%$ & $2 \%$ & $3 \%$ & $3 \%$ & $2 \%$ \\
\hline SDG 3 & $8 \%$ & $12 \%$ & $13 \%$ & $14 \%$ & $14 \%$ \\
\hline SDG 4 & $9 \%$ & $12 \%$ & $14 \%$ & $15 \%$ & $14 \%$ \\
\hline
\end{tabular}

Vol. 19, No. 3 
Reporting on Sustainable Development Goals. A score-based approach with companylevel evidence from Central-Eastern Europe economies

\begin{tabular}{|c|c|c|c|c|c|}
\hline SDG/Year & 2015 & 2016 & 2017 & 2018 & 2019 \\
\hline SDG 5 & $8 \%$ & $10 \%$ & $13 \%$ & $13 \%$ & $10 \%$ \\
\hline SDG 6 & $12 \%$ & $14 \%$ & $15 \%$ & $17 \%$ & $14 \%$ \\
\hline SDG 7 & $11 \%$ & $13 \%$ & $16 \%$ & $18 \%$ & $13 \%$ \\
\hline SDG 8 & $12 \%$ & $15 \%$ & $18 \%$ & $20 \%$ & $16 \%$ \\
\hline SDG 9 & $10 \%$ & $13 \%$ & $15 \%$ & $15 \%$ & $12 \%$ \\
\hline SDG 10 & $5 \%$ & $5 \%$ & $7 \%$ & $9 \%$ & $6 \%$ \\
\hline SDG 11 & $8 \%$ & $10 \%$ & $11 \%$ & $14 \%$ & $11 \%$ \\
\hline SDG 12 & $11 \%$ & $15 \%$ & $16 \%$ & $18 \%$ & $15 \%$ \\
\hline SDG 13 & $12 \%$ & $14 \%$ & $16 \%$ & $18 \%$ & $15 \%$ \\
\hline SDG 14 & $3 \%$ & $4 \%$ & $4 \%$ & $5 \%$ & $5 \%$ \\
\hline SDG 15 & $4 \%$ & $7 \%$ & $6 \%$ & $9 \%$ & $9 \%$ \\
\hline SDG 16 & $4 \%$ & $4 \%$ & $4 \%$ & $6 \%$ & $5 \%$ \\
\hline SDG 17 & $10 \%$ & $13 \%$ & $16 \%$ & $16 \%$ & $15 \%$ \\
\hline
\end{tabular}

The highest value was recorded for SDG 8 with a maximum accomplishment rate of $20 \%$ in 2018. This shows the companies concern for the safety of their employees. In many cases companies established quantitative targets to diminish the number of work accidents and measured their efforts as the safe production is crucial to economic growth.

Fairly close high values were obtained for 9 goals related to human health; quality education; clean water, energy, and air; innovation; sustainable communities; responsible consumption and production; and partnerships. As noticeable in Table 10 , there is a significant gap between the values of the above-mentioned goals and those for SDG 10,14, 15, and 16. Considering that the chemical sector counts more than 20 million employees worldwide, the chemical manufacturers should have advocated for equality. Furthermore, this sector should be more aware of the marine pollution and biodiversity than any other sector.

The smallest values were recorded for SDGs referring to combating poverty and hunger, although the SDG 2 was set as a priority goal for the chemical sector (WBCSD, 2018).

A deeper analysis was conducted to determine the degree of compliance of the reported SDGs with the goals where the chemical sector can have the greatest impact. To the ten key goals set for the chemical sector and described in the methodology section, SDG 17 may be added as it is recognized that the spirit of partnership and collaboration it embodies is a recurring theme throughout all the 
sustainable development goals, resulting in 10 plus 1 priority goals (WBCSD, 2018).

Considering the values obtained for the SGDs, the 10 plus 1 key goals in the chemical sector of the five analysed countries are: SDG 3, SDG 4, SDG 5, SDG 6, SDG 7, SDG 8, SDG 9, SDG 11, SDG 12, and SDG 13 plus SDG 17. As shown in Table 11, there is an exact match for 8 plus 1 priority goals, revealing a compliance of almost $82 \%$.

Table 11. Comparative key goals for the chemical sector

\begin{tabular}{|c|c|c|c|c|c|c|c|c|c|c|c|c|c|c|c|c|}
\hline SDG & 1 & 2 & 3 & 4 & 5 & 6 & 7 & 8 & 9 & 10 & 11 & 12 & 13 & $\begin{array}{ll}14 & 15\end{array}$ & 16 & 17 \\
\hline $\begin{array}{l}\text { Key SDG's } \\
\text { (WBCSD, } \\
\text { 2018) }\end{array}$ & & $\checkmark$ & $\checkmark$ & & & $\checkmark$ & $\checkmark$ & $\checkmark$ & $\checkmark$ & & $\checkmark$ & $\checkmark$ & $\checkmark$ & $\checkmark$ & & $\checkmark$ \\
\hline $\begin{array}{l}\text { Key SDG's } \\
\text { (Authors' } \\
\text { findings) }\end{array}$ & & & $\checkmark$ & $\checkmark$ & $\checkmark$ & $\checkmark$ & $\checkmark$ & $\checkmark$ & $\checkmark$ & & $\checkmark$ & $\checkmark$ & $\checkmark$ & & & $\checkmark$ \\
\hline
\end{tabular}

Significant differences were found for two of the goals - SDG 2 and SDG 14. Although set in the priority list, the goals related to ending hunger and conserving marine biodiversity did not accumulate the expected score. As chemistry is essential to the global food value chain, enabling higher yields, and improved nutrition, the chemical sector companies should be more involved in actions that contribute to sustainable and healthy food supply. Additionally, this sector should collaborate with others in the value chain on aquatic waste issues, improving water quality by reducing pollution and protect marine and coastal ecosystems. By contrast, the analysis revealed other two key goals: SDG 4 and SDG 5. The chemical sector supported the quality of education through investments and scholarships in universities, but especially through technical apprenticeships useful for potential employees to improve their professional skills. Furthermore, we find as remarkable that the companies were concerned by gender equality. The companies from the chemical sector supported the participation of women and were involved in diminishing the gender gap, also by emphasising the number of women occupying executive positions.

\section{Conclusion}

The model of sustainable development is unfamiliar and new for companies operating in Central-Eastern European (CEE) countries and in some way, this is considered a real challenge (Raszkowski \& Bartniczak, 2019).

This academic paper examines disclosure on the SDGs for a sample of large companies operating in the chemical industry operating in Czech Republic, 
Hungary, Poland, Romania, and Slovakia. The investigation covers the period 2015-2019. The initial sample consisted in 50 companies but we maintained only 35 firms after the refining process, adding up to a number of 114 firm-year observations (from 111 reports and 3 observations based on website only). All companies' reports and additional information were hand collected. In order to succeed in our research, the textual and content analysis was performed to study to what extent the companies describe the SDGs in their reports or on websites and to assess the general status of disclosure on the SDG topics using a score-based approach.

Although literature is rich in studies dealing with sustainable development, the majority of such studies approach a macroeconomic, country level analysis and there are none that quantify the impact on SDGs by approaching a company level, focusing on companies from the chemical sector in emerging economies from Europe. The paper has several significant contributions: it analyses the influence exerted on all SDGs, it highlights both the SDGs that benefit from substantial efforts and those SDGs which require further attention, and the paper is focused on the chemical sector, which is characterised by a high degree of complexity, and as such it interacts with a wide number of SDGs (WBCSD, 2018).

The results have indicated that $63 \%$ of the analysed reports did not specifically mention SDGs that were targeted by their efforts; this being partially explained by the fact that in 2015 the SDGs have just been set. The highest overall SDG score was obtained for SDG 8, adding up to a value of 462 out of a maximum of 875 , emphasising that companies are mostly concerned about the safety and well-being of their employees. This goal is closely followed by SDG 13 with a score of 430 and SDG 12 with a score of 427, which are strongly correlated with SDG 9 and SDG 17 scoring 399, also being situated above the average. SDG 3, SDG 4, SDG 5 and SDG 7 are other goals that recorded a score above the mean. The low-scoring goals are represented by SDG 15, SDG 10 and SDG 16, located below the mean, whereas SDG 14, SDG 1 and SDG 2 are situated at the end of the range.

From the total number of 35 companies included in the sample, 12 firms $(34.28 \%)$ record an average SDG score situated above the mean of 44.13. Another important finding is the extraordinary symmetry for the first and last places in SDGs completion hierarchy, but also for the distribution of companies compared to the chemical sector average. Hence, half of the analysed companies improve their SDGs implementing and reporting procedure to achieve a high level in reporting hierarchy, while the other half should manage SDGs in a better way to ensure a position at least above average.

The goals which were most reported on are SDG 12, SDG 13, and SDG 17, which were mentioned by more than $90 \%$ of the companies. Goals $4,5,6,7$ and 8 appeared in $80-90 \%$ of the companies, while SDG 3, 9, 10 and 15 were allocated 
by $60-80 \%$ of the companies. The lowest ranks were occupied by SDG 1, SDG 14 and SDG 16 located between $37-40 \%$, respectively SDG 2 reported only by $29 \%$ of the companies. The ranking confirms our initial expectations and it is significantly determined by the relation between the chemical sector particularities and the specificity of each SDG. These results are also consistent with our previous findings regarding the highest overall and average scores, and similar to the ones obtained by of Ionașcu et al. (2020) for the real estate sector.

There were 11 companies covering almost $29 \%$ of the sample which had a single report, out of which Linde Gas AS achieved the highest score, while the others did not exceed 43. For the rest of the companies (with more than 2 reports), a few (4) recorded high and medium constant values showing their great interest related to SDGs reporting, a large number (11) reflect a growing trend, while a smaller number (6) recorded a fluctuating trend over the analysed period, or even a declining trend (4 companies).

In terms of the analysis of SDGs score by years, the interest in reporting the SDGs achievements has an increasing trend in the first years from 2015 to 2018, followed by a decrease in the last year for all the sustainable development goals. The highest value was recorded for SDG 8 with an accomplishment maximum rate of $20 \%$ in 2018, fairly close high values were obtained for 9 goals (SDG 3, SDG 4, SDG 6, SDG 7, SDG 9, SDG 11, SDG 12, SDG 13 and SDG17) and, after a significant gap, SDG 10, 14, 15, and 16 are following. The smallest values were recorded for SDGs referring to combating poverty and hunger, although the SDG 2 was set as a priority goal for the chemical sector (WBCSD, 2018).

A deeper analysis was conducted in comparison to the same WBCSD roadmap, where 10 plus 1 key goals are set for the chemical sector, the values obtained for the SGDs disclose an exact match for 8 plus 1 priority goals, meaning a compliance of almost $82 \%$. However, significant differences were found for two of the goals - SDG 2 and SDG 14.

As chemistry is essential to the global food and aquatic waste value chain, the chemical sector companies should be more involved in actions that contribute to sustainable and healthy food supply and improving water quality by reducing pollution and protect marine and coastal ecosystems. In addition, the analysis revealed other two key goals: SDG 4 and SDG 5. The chemical sector supported the quality of education through investments and scholarships in universities, but especially through technical apprenticeships useful for potential employees to improve their professional skills. Furthermore, it is remarkable that the companies were concerned by the gender equality. The companies from the chemical sector supported the participation of women and were involved in diminishing the gender gap, also by emphasising the number of women working in executive positions. 
Besides the pertinent findings, the paper has its own limitations: firstly, the handcollecting data is time consuming and prone to biases; the inaccuracy of textual analysis is too generous to draw meaningful extrapolations about the relationships implied by data release through reports. Even though we applied joint efforts in developing the score, the researchers' subjectivity is not eliminated. As designers of this study, we confronted unstructured reports and numerous times group reports instead of individual local company reports which are not relevant for a country level analysis. UN proposes a set of 17 goals (SDG) with a total of 169 specific targets which were not separately investigated, by contrast, this research considers a general description, qualitatively and quantitatively, of each SDG.

Our further work will concentrate in expanding the database and adding financial information to recognise and examine the relationship between financial figures and non-financial data, articulated as SDGs.

Our research is relevant for the academic community contributing to the debate concerning SDGs disclosure and progress, and to broaden the theoretical writings based on content analysis of non-financial reports, as well for businesses to advance in their engagements and reporting on the topic of SDGs.

\section{Acknowledgments}

This research paper has been prepared as a part of the Human Capital Operational Program 2014-2020, project number POCU/380/6/13/125245 no. 36482/23.05.2019, "Excellence in interdisciplinary Ph.D. and post-Ph.D. research, career alternatives through entrepreneurial initiative (EXCIA)", coordinated by the Bucharest University of Economic Studies.

\section{References}

ACCA (2017) The Sustainable Development Goals: redefining context, risk and opportunity, available online at: https://www.accaglobal.com/hk/en/ professional-insights/global-profession/the-sustainable-developmentgoals.html, accessed 15 July, 2020

Accountancy Europe (2020) Towards reliable non-financial information across Europe, available online at: https://www.accountancyeurope.eu/publications/ towards-reliable-non-financial-information-across-europe/ accessed 1 September, 2020

Adams, C.A, Druckman, P.B, \& Picot, R.C, (2020) Sustainable Development Goal Disclosure (SDGD) Recommendations, published by ACCA, Chartered Accountants ANZ, ICAS, IFAC, IIRC and WBA. 
Adams, C.A. (2020) Sustainable Development Goals Disclosure (SDGD) Recommendations: Feedback on the consultation responses, ACCA, IIRC, WBA

Adelson, G., Engell, J., Ranalli, B. \& Van Anglen, K.P. (2008) Environment: An Interdisciplinary Anthology, New Haven and London: Yale University Press, available online at: https://www.jstor.org/stable/j.ctt5vkqnr, accessed 15 June, 2020

Aga, R. (2012) "The strength of the chemical industry: managing multidisciplinary business and R\&D”, Chemical Industry, no. 505: 20-29

Albu, C.N., Balsari, C. \& Krasodomsk, J. (2016) "Introduction to the Special issue on Corporate Social Reporting in Central and Eastern Europe", Accounting and Management Information Systems, vol. 15, no. 2: 193-205

Albu, N., Albu, C.N., Dumitru, M. \& Dumitru, V.F. (2013) "Plurality or convergence in sustainability reporting standards?", Amfiteatru Economic, vol. XV, no. 7: 729-743

Albu, N., Albu, C.N., Girbina, M.M. \& Sandu, I.M. (2011) "The implications of corporate social responsibility on the accounting profession: the case of Romania", Amfiteatru Economic, vol. XIII, no. 29: 221-234

Allen, C., Metternicht, G. \& Wiedmann, T. (2018) „Initial progress in implementing the Sustainable Development Goals (SDGs): A review of evidence from countries", Sustainability Science, no.13: 1453-1467 published online, https://doi.org/10.1007/s11625-018-0572-3

Aras, G. \& Crowther, D. (2008) „Governance and sustainability: An investigation into the relationship between corporate governance and corporate sustainability", Management Decision, vol. 46, no. 3: 433-448

Ariano, I.G. \& Hategan, C.D. (2019) "The Stage of Corporate Social Responsibility in EUCEE Countries", European Journal of Sustainable Development, vol. 8, no. 3: 340-353

Balcerowicz-Szkutnik, M., Szkutnik, W. \& Szkutnik, W. (2020) „Sustainable development goals as a challenge for national and global development", SHS Web of Conferences 74, 05006, available online at: https://doi.org/10.1051/shsconf/20207405006, accessed 15 July, 2020

Baleanu, T.E., Chelcea, L., \& Stancu, A. (2011) "The social responsibility of the top 100 Romanian companies. An analysis of corporate websites", Amfiteatru Economic, vol. XIII, no. 29: 235-248

Ballou, B., Casey, R.J., Grenier, J.H., Heitger, L.D. (2011) "Exploring the strategic integration of sustainability initiatives: opportunities for accounting research", Accounting Horizons, vol. 26, no. 2

Beattie, V. (2014) "Accounting narratives and the narrative turn in accounting research: Issues, theory, methodology, methods and a research framework", The British Accounting Review, vol. 46, no. 2: 111-134 
Bebbington, J. \& Larrinaga, C. (2014) "Accounting and sustainable development: An exploration Accounting", Organizations and Society, vol. 39, no.6: 395-413

Bebbington, J. \& Unerman, J. (2018) "Achieving the United Nations Sustainable Development Goals. An enabling role for accounting research", Accounting, Auditing and Accountability Journal, vol. 31, no.1: 2-24.

Bebbington, J. (2007) Accounting for Sustainable Development Performance, CIMA Publishing, Published by Elsevier Ltd

Bonini, S. and Swartz, S. (2014) Profits with purpose: How organizing for sustainability can benefit the bottom line, available online at: https://www.mckinsey.com/ /media/McKinsey/Business\%20Functions/Sust ainability/Our\%20Insights/Profits\%20with\%20purpose/Profits\%20with\%20 Purpose.pdf, accessed July 2020

Brunelli, S. \& Ranalli, F. (2020) "SDGs achievement: commitment, channels of action and the role of integrated reporting in the disclosure mechanisms", In S. Brunelli \& E. Di Carlo (eds.) Accountability, Ethics and Sustainability of Organizations, Accounting, Finance, Sustainability, Governance \& Fraud: Theory and Application, Springer

Burchell, S., Clubb, C., Hopwood, A. \& Hughes, J. (1980) "The roles of accounting in organizations and society", Accounting, Organizations and Society. vol. 5, no. 1: 5-21

Calabrese, A., Costa, R., Levialdi, N. \& Menichini, T. (2016) „A fuzzy analytic hierarchy process method to support materiality assessment in sustainability reporting", Journal of Cleaner Production, no.121: 248-264

Cefic (2017) Chemistry making a world of difference, European Chemical Industry Council - Cefic aisbl, available online at: https://chemistrycan.com/app/ uploads/2017/10/SD-Report2017.pdf, accessed 15 July 2020

Cefic (2020) Facts and figures of the European chemical industry, available online at https://cefic.org/app/uploads/2019/01/The-European-Chemical-IndustryFacts-And-Figures-2020.pdf, accessed July 2020

Cetindamar, D. \& Husoy, K. (2007) "Corporate social responsibility practices and environmentally responsible behavior: The case of the United Nations global compact", Journal of Business Ethics, vol. 76: 163-176

CGMA (2018) Creating a sustainable future. The role of the accountant in implementing the Sustainable Development Goals, available online at: https://www.cgma.org/content/dam/cgma/resources/reports/downloadabledo cuments/cgma-sustainable-dvelopment-goals-guide-apr-18.pdf

Chemical Sector SDG Roadmap (2018) available online at: https://docs.wbcsd.org/2018/07/Chemical_Sector_SDG_Roadmap.pdf, accessed 15 June, 2020

Cordova, M.F. \& Celone, A. (2019) "SDGs and Innovation in the Business Context Literature Review”, Sustainability, vol.11, no. 24: 1-14 
Costanza, R., Daly, L., Fioramonti, L., Giovannini, E., Kubiszewski, I., Mortensen, L.F., Pickett, K.E., Ragnarsdottir, K.V., De Vogli, R. \& Wilkinson, R., (2016) „Modelling and measuring sustainable wellbeing in connection with the UN Sustainable Development Goals", Ecological Economics, no. 130: 350-355

De Nuccio, E. (2020) From Non-Financial Disclosure to Integrated Reporting, available online at: https://www.ifac.org/knowledge-gateway/preparingfuture-ready-professionals/discussion/non-financial-disclosure-integratedreporting, accessed on July 2020

Deloitte (2019) Annual report insights 2019, Surveying FTSE reporting, available online at: https://www2.deloitte.com/uk/en/pages/audit/articles/annualreport-insights.html, accessed 15 July, 2020

Diaconu, G. (2012) "Comments on The relationship between environmental reporting and corporate governance characteristics of Romanian listed entities", Accounting and Management Information Systems, vol. 11, no. 2: 295-297

Directive (2014) "2014/95/EU of the European Parliament and of the Council. 2014. Disclosure of non-financial and diversity information by certain large undertakings and groups", Official Journal of the European Union https://eur-lex.europa.eu/legalcontent/EN/TXT/?uri=CELEX\%3A32014L0095

Dumitru, M., Dyduch, J., Guse, R.G., \& Krasodomska, J. (2017) "Corporate Reporting Practices in Poland and Romania - An Ex-Ante Study to the New Non-Financial Reporting European Directive", Accounting in Europe, vol. 14, no. 3: 279-304, DOI:10.1080/17449480.2017.1378427

Dumitru, V., Ionescu, I., Calu, A. \& Oancea, M. (2011) "An investigation regarding the disclosure of corporate social responsibility information for listed companies from Romania", Amfiteatru Economic, vol. 13, no. 29: 146-161

Dyczkowska, J., Krasodomska, J. \& Michalak, J. (2016) "CSR in Poland: Institutional context, legal framework and voluntary initiatives", Accounting and Management Information Systems, vol. 15, no. 2: 206-241

Easterly, W. (2015) „The trouble with the sustainable development goals”, Current History, vol. 114, no. 775: 322-324

Eccles, R.G., \& Krzus, M. (2010) One Report: Integrated Reporting for a Sustainable Strategy, New York: John Wiley \& Sons, 2010

Eccles, R.G., Schulschenk., J. \& Serafeim, G. (2012) "Capturing the link between non-financial and financial performance in one space", In Making Investment Grade: The Future of Corporate Reporting, edited by Cornis van der Lugt and Daniel Malan, 43-48. United Nations Environment Programme, available online at: https://www.hbs.edu/faculty/Publication\% 20Files/Capturing\%20the\%20Link\%20(chapter)\%20Eccles\%20Schulschenk \%20Serafeim_b766a775-fd22-4e6d-905e-c473d871c0e4.pdf, accessed on July 2020 
Epstein, M. \& Hanson, K. (2006) The Accountable Corporation. Praeger perspectives, Westport, Conn: Praeger Publisher

European Parliament's Committee on Development, (2019) Europe's approach to implementing the Sustainable Development Goals, available online at: https://www.europarl.europa.eu/cmsdata/160360/DEVE\%20study\%20on\%2 0EU\%20SDG\%20implementation\%20formatted.pdf, accessed 15 July, 2020

European Union (2019) EU reporting on sustainability and UN development goals still lacking, warn Auditors, available online at: https://www.eca.europa.eu/ en/Pages/NewsItem.aspx?nid=12287, accessed on July 2020

EY (2017) Non-financial data reporting. Value for companies and investors, available online at: https://www.ey.com/Publication/vwLUAssets/ESG_ Analysis_of_Companies_in_Poland/\$FILE/ESG-Analysis-of-Companies-inPoland.pdf, accessed on July 2020

EY (2017) Why Sustainable Development Goals should be in your business plan, available online at: https://www.ey.com/en_gl/assurance/why-sustainabledevelopment-goals-should-be-in-your-business-plan, accessed 15 July, 2020

EY (2018) Does your nonfinancial reporting tell your value creation story? available online at: https://www.ey.com/Publication/vwLUAssets/ey-ccasssurvey-2018-report/\$FILE/ey-ccass-survey-2018-report.pdf accessed 15 July, 2020

Fasan, M. (2013) "Annual reports, sustainability reports and integrated reports: trends in corporate disclosure", in C. Busco et al. (eds.) Integrated Reporting, Springer International Publishing Switzerland

Firmansyah, I. (2019) "The role of accountants in achieving Sustainable Development Goals: Academics Perspective", Jurnal Ilmiah Akuntansi dan Bisnis, vol. 14, no. 2

Fonseca, L. \& Carvalho, F. (2019) "The reporting of SDGs by quality, environmental, and occupational health and safety-certified organizations", Sustainability, vol. 11

Freeman, R.E. (1984) Strategic Management: A Stakeholder Approach, Boston: Pitman, 1984

Fritz, S. (2018) SDGs: a new focus for non-financial rating agencies, Novethic research centre, available online at: https://www.novethic.com/fileadmin// user_upload/tx_ausynovethicetudes/pdf_complets/Novethic_2018_NonFina ncial-Ratings-focus-on-SDGs.pdf, accessed on July 2020

Gazdar, K. (2007) Reporting Non-financials, John Wiley \& Sons Ltd, The Atrium, Southern Gate, Chichester

Gould, S. \& Lim, A. (2019) 5 Key Actions for Professional Accountancy Organizations (PAOs) to Advance the SDGs, available online at: https://www.ifac.org/knowledge-gateway/contributing-globaleconomy/discussion/5-key-actions-professional-accountancy-organizationspaos-advance-sdgs, accessed on July 2020 
Gray, R. \& Collison, D. (2002) "Can't see the wood for the trees, can't see the trees for the numbers? Accounting education, sustainability and the public interest", Critical Perspectives on Accounting, vol. 13: 797-836

Guthrie, J. \& Parker, L.D. (2006) "Corporate social disclosure practice: a comparative international analysis", Advances in Public Interest Accounting, vol. 3: 159-175.

Guthrie, J. \& Abeysekera, I. (2006) "Content analysis of social, environmental reporting: What is new?", Journal of Human Resource Costing \& Accounting, vol. 10, no. 2: 114-126

Gray, R. (2010) "Is accounting for sustainability actually accounting for sustainability. . . and how would we know? An exploration of narratives of organisations and the planet", Accounting, Organizations and Society, vol. 35: 47-62

Guşe, R.G., Almăşan, A., Circa, C. \& Dumitru, M. (2016) "The role of the stakeholders in the institutionalization of the CSR reporting in Romania", Accounting and Management Information Systems, vol. 15, no. 2: 304-340

Haller, A. (2016) "Value creation: a core concept of integrated reporting", in C. Mio (ed.), Integrated Reporting,

Hofstede, G., Hofstede, G.J., Minkov, M. (2010) Cultures and Organizations: Software of the Mind, McGraw-Hill.

Hummel, K. (2019) „Reporting on the Sustainable Development Goals - Early Evidence from Europe", available online at: https://ssrn.com/ abstract=3411017 or http://dx.doi.org/10.2139/ssrn.3411017, accessed on July 2020

Ienciu, A., Muller, V. \& Matiş, D. (2011) „Environmental reporting within the Romanian Companies", International Journal of Energy and Environment, vol. 5 , no. 1: $123-131$

IFAC (2016) The 2030 Agenda for Sustainable Development A Snapshot of the Accountancy Profession's Contribution, available online at: https://www.ifac.org/knowledge-gateway/developing-accountancyprofession/publications/2030-agenda-sustainable-development, accessed on July 2020

Ionașcu, E., Mironiuc, M., Anghel, I. \& Huian, M.C. (2020) „The involvement of real estate companies in sustainable development - an analysis from the SDGs reporting perspective”, Sustainability, vol. 12, no. 798:1-24

ISI Emerging Markets Group (2020) EMIS Platform, available online at: https://www.emis.com/companies, accessed June 2020

Izzo, M.F., Ciaburri, M. \& Tiscini, R. (2020) „The challenge of Sustainable Development Goal Reporting: The first evidence from Italian Listed Companies", Sustainability, vol.12, no. 8: 1-18

Jindrichovska, I. \& Purcărea, I. (2011) „CSR and Environmental Reporting in the Czech Republic and Romania: country comparison of rules and practices", Accounting and Management Information Systems, vol. 10, no. 2: 202-227 
Joyner, B.E. \& Payne, D. (2002) "Evolution and Implementation: A Study of Values, Business Ethics and Corporate Social Responsibility", Journal of Business Ethics 41: 297-311

Kaplan, R. \& D. Norton (2004) Strategy Maps: Converting Intangible Assets into Tangible Outcomes, Boston, MA: Harvard Business Press

Kasparova, K. (2018) "The Czech CSR reports: topics and quality of their processing", available online at: http://aak.slu.cz/pdfs/aak/2018/02/01.pdf, accessed 15 July, 2020

Khan, M., Lockhart, J. \& Bathurst, R. (2018) "Content analysis of corporate social responsibility disclosures: an assessment of approaches", ANZAM 2018/32nd ANZAMm Conference at: Auckland, New Zealand

Kornieieva, Y. (2020) "Non-financial reporting challenges in monitoring SDG`s achievement: investment aspects for transition economy", International Journal of Economics and Business Administration, vol. VIII, no. 1

KPMG (2011) International Survey of Corporate Responsibility Reporting, available online at: https://assets.kpmg/content/dam/kpmg/pdf/ 2012/02/Corporate-responsiblity-reporting-2012-eng.pdf, accessed 15 July, 2020

KPMG (2017) The KPMG Survey of Corporate Responsibility Reporting, available online at: https://home.kpmg/xx/en/home/insights/2017/10/the-kpmg-surveyof-corporate-responsibility-reporting-2017.html, accessed 15 July, 2020

KPMG (2020) Reporting the SDGs: How to get it right, available online at: https://home.kpmg/xx/en/home/insights/2020/01/reporting-sdgs-how-to-getit-right.html, accessed 15 July, 2020

La Torre, M., Sabelfeld, S., Blomkvist M., Tarquinio L. \& Dumay, J. (2018) "Harmonising non-financial reporting regulation in Europe: practical forces and projections for future research", Meditari Accountancy Resources, vol. 26: 598-621

Li, F. (2010) "Textual analysis of corporate disclosures: a survey of literature", Journal of Accounting Literature, vol. 29: 143-165

Lungu, C.I., Caraiani, C. \& Dascălu, C. (2011) "Research on corporate social responsibility reporting", Amfiteatru Economic, vol. XIII, no. 29:117-131

Makarenko, I. \& Plastun, A. (2017) "The role of accounting in sustainable development", Accounting and Financial Control, vol.1, no. 2

Matuszak, L. \& Rozanska, E. (2017) "CSR Disclosure in Polish-Listed Companies in the Light of Directive 2014/95/EU Requirements: Empirical Evidence", Sustainability, vol. 9, no. 12

McArthur, J.W. \& Rasmussen, K. (2019) „Classifying Sustainable Development goal trajectories: a country-level methodology for identifying which issues and people are getting left behind", World Development, vol. 123, no. $104608: 1-13$ 
Miola, A. \& Schiltz, F. (2019) „Measuring sustainable development goals performance: How to monitor policy action in the 2030 Agenda implementation?", Ecological Economics, vol. 164: 1-10

Nechita, E. (2019) „Analysis of the relationship between accounting and sustainable development. the role of accounting and accounting profession on sustainable development", Audit Financiar, vol. 17, no. 3: 520-536

Nechita, E., Manea, C.L., Irimescu, A.M, Nichita, E.M. (2020) "The content analysis of reporting on sustainable development goals", Audit Financiar, vol. 18, no. 160, forthcoming.

Ng, A., Leung, T.C.H. \& Lo, J.M.K. (2017) "Developing sustainability competence for future professional accountants: the integrative role of an undergraduate program", In Leal Filho W et al. (eds) Handbook of theory and practice of sustainable development in higher education, World sustainability series, Springer

Ngwakwe, C.C. (2012) "Rethinking the accounting stance on sustainable development", Sustainable Development, vol. 20, no. 1

Nichita, E.M. (2018) "Enhancing quality of information through risk reporting in financial statements", Proceedings of International Conference on Business Excellence, vol. 12, issue 1

Nicolai, S., Hoy, C., Berliner, T. \& Aedy, T. (2015) Projecting Progress: Reaching the SDGs by 2030; London: Overseas Development Institute, available online at: https://www.odi.org/sites/odi.org.uk/files/odi-assets/publicationsopinion-files/9938.pdf, accessed 15 July, 2020

OECD (2019) Measuring Distance to the SDG Targets 2019: An Assessment of Where OECD Countries Stand, OECD Publishing, Paris, available online at: https://doi.org/10.1787/a8caf3fa-en, accessed June 2020

Oprisor, T. (2015) "Contributions to an improved framework for integrated reporting", Accounting and Management Information Systems, vol. 14, no. 3: 483-507

Putter, J.M. (2017) "Corporate Sustainability Reporting: Summary and Conclusions", In P. Horvath, J.M. Putter (eds.), Sustainability Reporting in Central and Eastern European Companies, MIR Series in International Business

PwC (2018) From Promise to Reality: Does Business Really Care about the SDGs? And What Needs to Happen to Turn Words into Action; PwC: London, UK, available online at: https://www.pwc.com/gx/en/ sustainability/SDG/sdg-reporting-2018.pdf accessed June 2020

PwC (2019) Creating a strategy for a better world How the Sustainable Development Goals can provide the framework for business to deliver progress on our global challenges, available online at: https://www.pwc.com/gx/en/sustainability/SDG/sdg-2019.pdf, accessed June 2020 
Ramirez, G.A. (2012) „Sustainable development: paradoxes, misunderstandings and learning organizations", The Learning Organization, vol.19, no.1:58-76

Raszkowski, A. \& Bartniczak, B. (2019) „Sustainable Development in the Central and Eastern European Countries (CEECs): Challenges and Opportunities", Sustainability, vol. 11, no. 4: 1-18

Rezaee, Z. \& Tuo, L. (2017) "Voluntary disclosure of non-financial information and its association with sustainability performance", Advances in Accounting, vol. 39: 47-59

Rolland, D. \& Bazzoni, J.O. (2009) "Greening corporate identity: CSR online corporate identity reporting", Corporate Communications an International Journal, vol. 14, no. 3: 249-263

Rosati, F. \& Faria, L.G. (2019), „Addressing the SDGs in sustainability reports: The relationship with institutional factors", Journal of Cleaner Production, no. 215 : $1312-1326$

Schaltegger, S., Etxeberria, I.A. \& Ortas, E. (2017) "Innovating corporate accounting and reporting for sustainability - attributes and challenges", Sustainable Development, vol. 25:113-122

Schramade, W. (2017) „Investing in the UN Sustainable Development Goals: Opportunities for Companies and Investors", Journal of Applied Corporate Finance, vol.29, no. 2: 87-100

Scrieciu, S. (2007) „The inherent dangers of using computable general equilibrium models as a single integrated modelling framework for sustainability impact assessment. A critical note on Böhringer and Löschel (2006)", Ecological Economics, no. 60: 678-684

Sedlacek J. (2020) "Non-Financial Reporting of Industrial Corporations - A Czech Case Study", Acta Universitatis Agriculturae et Silviculturae Mendelianae Brunensis, vol. 68, no. 3: 625-636

Swain, R.B. \& Yang-Wallentin, F. (2019) „Achieving sustainable development goals: predicaments and strategies", International Journal of Sustainable Development \& World Ecology, vol. 27: 96-106

Tiron-Tudor, A., Nistor, C.S., Ștefănescu, C.A. \& Zanellato, G. (2019) "Encompassing non-financial reporting in a coercive framework for enhancing social responsibility: Romanian listed companies' case", Amfiteatru Economic, vol. 21, no. 52: 590-606

Turturea, M. (2016) "Assessing the actual stage of social and environmental reporting of the companies listed at Bucharest Stock Exchange", Accounting and Management Information Systems, vol. 15, no. 1:90-111

United Nations (2015) Transforming our world: the 2030 Agenda for Sustainable Development, available online at https://sustainabledevelopment.un.org/ content/documents/21252030\%20Agenda\%20for\%20Sustainable\%20Devel opment $\% 20$ web.pdf, accessed June 2020 
Waniak-Michalak, H., Macuda, M. \& Krasodomska, J. (2016) "Corporate Social Responsibility and accounting in Poland: a literature review", Accounting and Management Information Systems, vol. 15, no. 2: 242-303

WBCSD (2018) Chemical Sector SDG Roadmap, available online at https://docs.wbcsd.org/2018/07/Chemical_Sector_SDG_Roadmap.pdf, accessed June 2020

Zeghal, D. \& Ahmed, S.A. (1990) "Comparison of social responsibility information disclosure media used by Canadian firms", Accounting, Auditing \& Accountability Journal, vol. 3, no. 1: 38-53

Zimara, V. \& Eidam, S. (2015) "The benefits of social sustainability reporting for companies and stakeholders - Evidence from the German chemical industry", Journal of Business Chemistry, vol. 12, no. 3: 85-103

*** https://www.azomures.com/wp-content/uploads

*** http://www.borsodchem-group.com/About-us/Sustainability.aspx

*** http://www.boryszew.com.pl/1165

*** https://www.chemlandscape.cefic.org/

*** https://ciechgroup.com/en/relacje-inwestorskie/reports/periodical-reports/

$* * *$ https://www.colas.com/

$* * * \quad$ http://www.deza.cz/en/

*** https://data.worldbank.org/

*** https://www.duslo.sk/en/sustainability

*** https://www.enagro.sk/en/profile/sustainability-and-certification

*** https://www.fortischem.sk/en/sustainable-development

*** https://www.gsk.com/en-gb/investors/corporate-reporting/corporatereporting-archive/

*** https://www.hankooktire.com/global/sustainability.html

*** https://www.hartmann.info/en-corp

*** https://www.henkel.com/investors-and-analysts

*** https://www.ilo.org/global/industries-and-sectors/chemical-industries/lang-en/index.htm

*** https://www.jnj.com/sustainability-reporting

*** https://kmginternational.com/sustainability

*** https://www.krka.biz/en/for-investors/financial-reports/

*** https://www.linde.com/

*** https://molgroup.info/en/sustainability/reports-and-data

*** www.novartis.com/files/novartis-in-society-report-2019.pdf

*** http://www.oltchim.ro/en/index.php?name=investors-relation/sustainabilityreport

*** https://www.phoenixgroup.eu/en/sustainability/sustainability-report

*** https://www.polpharma.pl/odpowiedzialnosc-spoleczna/

*** https://report.basf.com

*** http://www.richter.hu/en-US/corporate-responsibility/Pages/Sustainabledevelopment.aspx 
Reporting on Sustainable Development Goals. A score-based approach with companylevel evidence from Central-Eastern Europe economies

*** https://www.sanofi.com/en/investors/reports-and-publications/financial-andcsr-reports

*** https://silon.in/company/sustainability/

*** https://www.synthosgroup.com/en/synthos-group/group/synthos-dwory7/quality-environment-safety

*** https://slovnaft.sk/en/about-us/sustainable-development-and-hse/

*** http://www.sopharmagroup.com/en/investor/financial-reports

*** https://www.sunpharma.com/responsibility/csr

*** https://tarnow.grupaazoty.com/en/relacje-inwestorskie/periodicreports\#item 4807

*** https://www.teva.cz/

*** https://www.unilever.com/sustainable-living/our-sustainable-living-reporthub/

*** https://www.unipetrolrpa.cz/en/AboutUs/Pages/AnnualReports.aspx

*** https://www.zentiva.ro/investors/financial-reports 


\section{Appendix 1. List of Sustainable Development Goals (UN, 2015)}

\begin{tabular}{|c|c|}
\hline Goal 1 & End poverty in all its forms everywhere \\
\hline Goal 2 & $\begin{array}{l}\text { End hunger, achieve food security and improved nutrition and promote } \\
\text { sustainable agriculture }\end{array}$ \\
\hline Goal 3 & Ensure healthy lives and promote well-being for all at all ages \\
\hline Goal 4 & $\begin{array}{l}\text { Ensure inclusive and equitable quality education and promote lifelong learning } \\
\text { opportunities for all }\end{array}$ \\
\hline Goal 5 & Achieve gender equality and empower all women and girls \\
\hline Goal 6 & $\begin{array}{l}\text { Ensure the availability and sustainable management of water and sanitation for } \\
\text { all }\end{array}$ \\
\hline Goal 7 & Ensure access to affordable, reliable, sustainable, and modern energy for all \\
\hline Goal 8 & $\begin{array}{l}\text { Promote sustained, inclusive, and sustainable economic growth, full and } \\
\text { productive employment and decent work for all }\end{array}$ \\
\hline Goal 9 & $\begin{array}{l}\text { Build resilient infrastructure, promote inclusive and sustainable } \\
\text { industrialization and foster innovation }\end{array}$ \\
\hline Goal 10 & Reduce inequality within and among countries \\
\hline Goal 11 & Make cities and human settlements inclusive, safe, resilient and sustainable \\
\hline Goal 12 & Ensure sustainable consumption and production patterns \\
\hline Goal 13 & Take urgent action to combat climate change and its impacts* \\
\hline Goal 14 & $\begin{array}{l}\text { Conserve and sustainably use the oceans, seas, and marine resources for } \\
\text { sustainable development }\end{array}$ \\
\hline Goal 15 & $\begin{array}{l}\text { Protect, restore, and promote the sustainable use of terrestrial ecosystems, } \\
\text { sustainably manage forests, combat desertification, and halt and reverse land } \\
\text { degradation and halt biodiversity loss }\end{array}$ \\
\hline Goal 16 & $\begin{array}{l}\text { Promote peaceful and inclusive societies for sustainable development, provide } \\
\text { access to justice for all and build effective, accountable, and inclusive } \\
\text { institutions at all levels }\end{array}$ \\
\hline Goal 17 & $\begin{array}{l}\text { Strengthen the means of implementation and revitalize the Global Partnership } \\
\text { for Sustainable Development }\end{array}$ \\
\hline
\end{tabular}

\section{Appendix 2. Assigning score procedure}

Capture from the 2017 Social impact report:

\begin{tabular}{llllll} 
Targets to 2020 & 2013 & 2014 & 2015 & 2016 & 2017 \\
\hline $\begin{array}{l}\text { Reduce greenhouse gas emissions by } 15 \% \\
\text { (baseline 2012) }\end{array}$ & $-4 \%$ & $-8 \%$ & $-14 \%$ & $-23 \%$ & $-32 \%$ \\
\hline
\end{tabular}

The score assigned to SDG 13 was 5 , as the company disclosed the quantitative target $(\mathrm{Tq})$, namely reducing greenhouse gas emissions by $15 \%$, but also the quantitative assessment of the obtained results on the progress towards the SDG target (Mq) by mentioning the reduction of 32\% compared to 2012 . 
Reporting on Sustainable Development Goals. A score-based approach with companylevel evidence from Central-Eastern Europe economies

Appendix 3. SDGs average score matrix

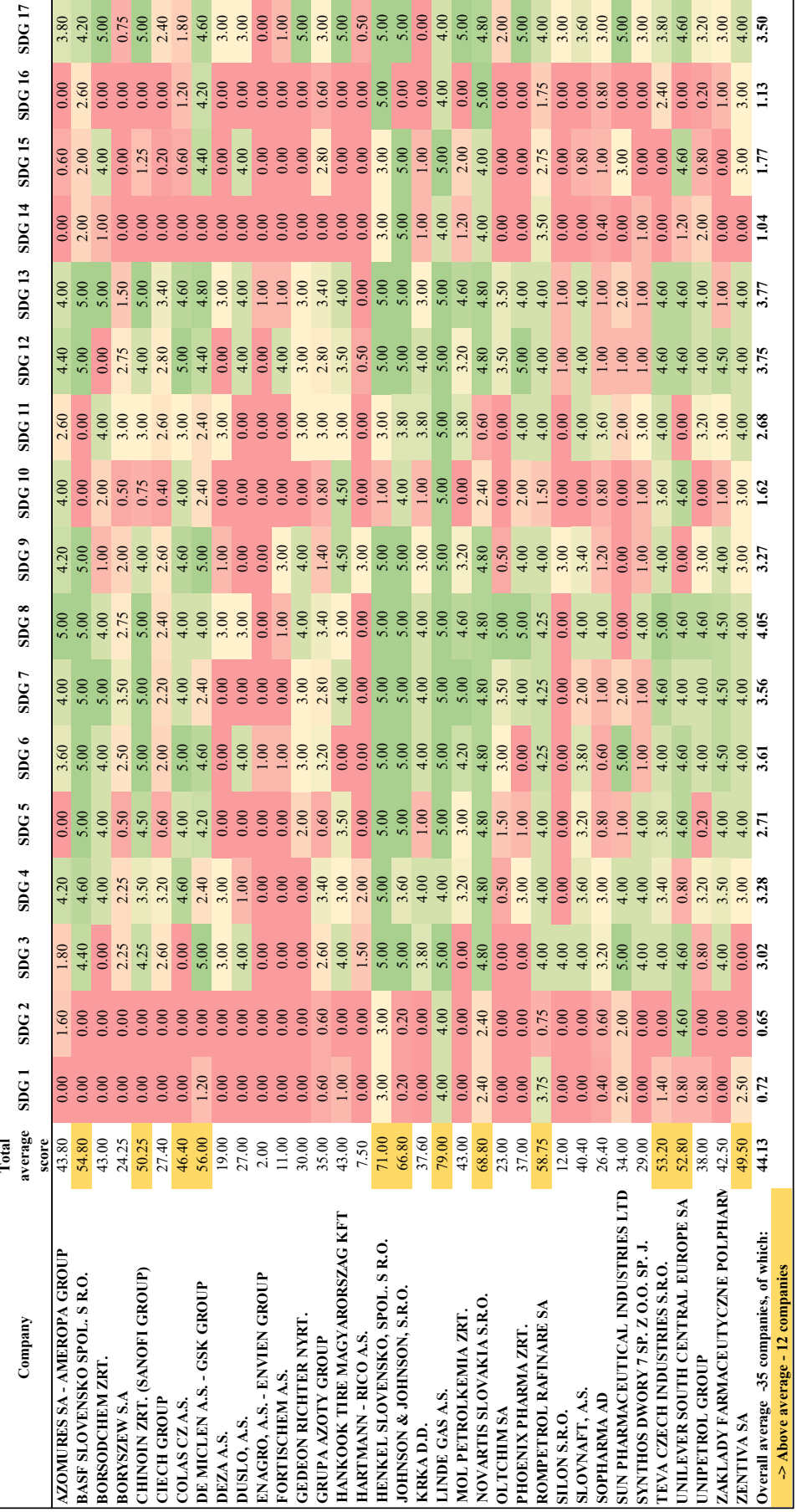

